\title{
DETOXIFICATION AND GENERATION OF USEFUL PRODUCTS FROM COAL COMBUSTION WASTES
}

Final Technical Report

Work Pertormed Under Cortract No. +\$22-88PC88910

For

U.S. Department of Energy

Pittsburgh Energy Technology Center

Plitsburgh, Pennsylvania

By

Arkansas Tech University

Russellville, Arkansas 


\section{DISCLAIMER}

This report was prepared as an account of work sponsored by an agency of the United States Goverument. Neither the United States Government nor any agency thereof, nor any of their empioyees, makes any warranty, express or implied, or assumes any legal liability or responsibility for the accuracy, completeness. or usefulness of any information, apparatus, product, or process disclosed, or represents that its use would not infringe privately owned rights. Reference herein to any specific commercial product, process. or service by trade name. trademark. manufactures, or otherwise does not necessarily constutute or imply its endorsement, recommendation. or favoring by the United States Government or any agency thereof. The views and opinions of authors ex pressed herein do not necessarily state or reflect those of the United States Government or any agency thereof.

This report has been reproduced directly from the best available copy.

Available to DOE and DOE contractors from the Office of Scientific and Technical Information, P.O. Box 62, Oak Ridge, TN 37831; prices available from $(615) 576 \cdot 8401$, FTS 626.8401 .

Available to the public from the National Technical Information Service, U.S. Department of Commerce, 5285 Port Royal Rd., Springfield, VA 22161 
$\mathrm{DOE} / \mathrm{PC} / 88910--8$

DE9 1006728

\section{DETOXIFICATION AND GENERATION OF USEFUL PRODUCTS FROM COAL COMBUSTION WASTES}

Final Technical Report

Project DE-FG22-88PC88910

$$
\text { For }
$$

U.S. Department of Energy

Pittsburgh Energy Technology Center

Pittsburgh, Pennsylvania

By

Arkansas Tech University

Russeliville, Arkansias 
FINAL TECHNICAL REPORT TO THE

Revised $11-21-90$

U.S. DE.PARTMENT OF ENERGY

\section{Project DE-FG22-88PC88910 \\ Detoxification and Generation of Useful \\ Products from Coal Combustion Wastes}

\section{Introduction:}

Electric utilities are on the brink of a new era in waste disposal problems that will stem from newly enacted acid rain legislation and pressure from the environmental community to reduce all emissions including sulfur dioxide. In order to meet these new requirements, power plants will be engaged in practices ranging from fuel switching to the installation of complete scrubber systems. The ultimate effect of an overall reduction in emissions will be an increase in the quantity and type of solid waste that will need to be disposed of by coalfired power plants. This research project addresses the issue of how to effectively dispose of flyash, bottom ash, and desulfurization sludge through the generation of chemically-hardened material that could potentially be used as a cement or as a synthetic aggregate.

In other parts of the world where local raw materials are scarce (notably in Japan and areas of Europe), by-products from the combustion of coal are used extensively for building materials. These building materials have a variety of forms and many of them are high strength. If a similar strategy were adopted in the U.S. to take waste products from the coal-fired power plants and generate synthetic cement/aggregates from these wastes, then many areas with inadequate ash disposal sites would benefit. The cost of generating this chemically formed aggregate would likely be offset by the reduced cost of disposing of the waste products at the power plant site.

One method of disposing of ash is to utilize it to generate useful products; however, only about 20 percent of all ash that is generated can be 
utilized, principally for cement manufacture (Schively, 1977). In addition, the pattern of utilization varies from state to state. In Florida, for example, nearly all flyash that is generated from coal-burning power plants is consumed by the cement industry and virtually none is available for other uses.

Depending on the type of burner used, between 20 and 80 percent of the ash in coal will. leave a coal-fired power plant as flyash with the remainder forming bottom ash. Scrubbing of the flue gasses to remove sulfur produces flue gas desulfurization sludge (DSG) consisting principally of impure gypsum. These byproducts generate environmental problems because of their chemical composition and the volume of material that must be disposed of. The large volumes of ash and DSG that must be handled on or near the site represent only a minimal problem in rural areas, but in urban areas lack of space and/or geological conditions make disposal very difficult, if not impossible.

\section{Review of the Literature:}

Uses for flyash as a pozzolan (i.e., a siliceous material which, when lime is added to it, will precipitate insoluble cementitious silicates) have long been recognized and a large number of techniques utilizing flyash have been described (Bucklen, et al, 1965; Faber, et al, 1976). Research in flyash utilization has been primarily external to the United States (Ravina, 1979). Little information has been published about the relative strengths of flyash lime cements; however, a mixture of gravel, flyash, and slaked lime derived from a dolomite gave compressive strengths of 162 and $194 \mathrm{~kg} / \mathrm{cm}^{2}$ after 7 and 14 days (Webster and Smith, 1971). Ground blast furnace slag having properties very similar to flyash was mixed with lime and cured for two weeks producing a product that had a compressive strength of $100 \mathrm{~kg} / \mathrm{cm}^{2}$ (Yamamoto, et al, 1977). The effect of strengthening agents on flyash and ground slag cement mixes is unknown. Silica 
gel and lime have been used as binders to produce lightweight building materials out of flyash; however, strengths for such material were not reported (Oates, 1974). Mixtures of calcium oxide and calcium chloride are known to enhance both the tensile and compressive strengths of portland cements and there is no reason to believe that it would no be equally as effective on flyash cements (Simeonov and Dzhabarov, 1978).

Mixtures of power plant flyash, quicklime and gypsum (or other sulfate containing materials) as an activator were found to have a compressive strength of approximately $100 \mathrm{~kg} / \mathrm{cm}^{2}$ which could be increased to $200-300 \mathrm{~kg} / \mathrm{cm}^{2}$ by heat treating (Grzymek and Malolepszy, 1973). Binders made from lignite ash, ground slag, and calcium sulfate hydrate were cured under hydrothermal conditions and found to create a cement having compressive strengths ranging between 50 and 400 $\mathrm{kg} / \mathrm{cm}^{2}$ (Savinkina and Logvinenko, 1974). A composition of calcium sulfate hemihydrate, clay, and flyash was found to give a hardened product with a compressive strength of $670 \mathrm{~kg} / \mathrm{cm}^{2}$ and a bending strength of $132 \mathrm{~kg} / \mathrm{cm}^{2}$ (Baselsen, 1977). Mixtures of desulfurization gypsum and granulated slag have been used as a soil cement (Hasaba and Torii, 1979). Similar soil stabilization cements can be generated from flyash, gypsum, and a small amount of either portland cement, ground blast furnace slag, or calcium hydxoxide. When this mixture was mixed with soil in amounts of only $3 \frac{1}{2}$ percent it gave compressive strengths of up to $40 \mathrm{~kg} / \mathrm{cm}^{2}$ after 28 days (Soc. Des Ciments Francais). All of the flyash/gypsum/lime mixtures have the common characteristic of forming not only calcium silicate hydrates and calcium aluminate hydrates but also ettringite as a binder (Lucas, 1980).

Granulated blast Eurnace slag was mixed with gypsum, calcium hydroxide, and water and stirred at $50-100^{\circ} \mathrm{C}$ to produce ettringite fibers. When these fibers were compacted at $170^{\circ} \mathrm{C}$ and $200 \mathrm{~kg} / \mathrm{cm}^{2}$ after mixing with 25 percent organic pulp, 
a product was obtained with a bending strength of $80 \mathrm{~kg} / \mathrm{cm}^{2}$ (Kondo, et al, 1979). Ettringite fibers were also obtained from a mixture of blast furnace slag, anhydrite, calcium hydroxide and water agitated at $50-100^{\circ} \mathrm{C}$ (Kondo and Fujisawa, 1974). Ground blast furnace slag and mixtures of gypsum and flue gas desulfurization gypsum along with sodium hydroxide, potassium hydroxide or calcium hydroxide can be used to make ettringite (Chudo, et al, 1978). Ettringite fibers can also be generated using aluminous cement, gypsum, quicklime and water (Caspar and Gaillard, 1980). Fibers of gypsum can also be crystallized directly through the reaction of sodium sulfate and calcium chloride at an elevated temperature and $\mathrm{pH}$ (Sueddeutsche Kalkstickstoff, 1976). The strength of cement can also be increased through the generation of ettringite by the addition of aluminum sulfate and calcium chloride (Simeonov and Dzhabarov, 1973). Ettringite fibers can be directly mixed with gypsum to produce high strength, high fire resistant wallboard and also mixed with siloxanes and compacted to produce extremely high strength, high density wallboards with a compressive strength of $90 \mathrm{~kg} / \mathrm{cm}^{2}$.(Kaga, et al, 1976; Oguri and Hashimi, 1973; Kubo and Sedo, 1977).

Cement can be rapidly hardened by the addition of gypsum and calcium chloride, gypsum and aluminum chloride, calcium fluoro-aluminate, or gypsum and aluminum sulfate producing compressive strengths of greater than $100 \mathrm{~kg} / \mathrm{cm}^{2}$ (Nakagawa, et al, 1977; Simeonov and Dzhabarov, 1977; Ichimura, et al, 1979). Mixtures of ettringite and gypsum fibers along with organic fibers have been hardened using calcium alumino-sulfates, aluminum hydroxide/calcium oxide, and pozzolan/sodium silicate mixtures (Kanno and Higaski, 1977; Hayashi, 1976; Mineshita, et a1, 1977; Mineshita and Imai, 1979). In addition to the hardening of ettringite cements some research has been performed on hardening red mud from bauxite processing. The red mud contains iron hydroxides and calcium silicates 
which when mixed with calcium hydroxide and a sulfate ( potassium sulfate, or gypsum) gave compressive strengths of up to 83 tons $/ \mathrm{m}^{2}$ after seven days (Mori and Kitsugi, 1974). Hardening agents for solidifying soils can be generated from separate sclutions of sodium silicate and a suspension of gypsum and calcium hydroxide which when mixed will set in the soil (Nitto Chemical Industry Company, 1980). A high strength cement may also be generated from a mixture of portland cement and flyash hardened with a sodium oxalate/sodium silicate solution. This mixture gave a compressive strength of 51 and $248 \mathrm{~kg} / \mathrm{cm}^{2}$ after une day and year respectively (Fujiko, 1980). Mixtures of lime and residue from pyrite roasting and ferruginous slags developed strengths ranging from 92 to $156 \mathrm{~kg} / \mathrm{cm}^{2}$ after autoclaving (Mukhamedbaeva, et al, 1972). Porous lightweight products were obtained with aluminum hydroxides and phosphoric acids which gave materials with compressive strengths ranging from 23 to $70 \mathrm{~kg} / \mathrm{cm}^{2}$ (Abyzov and Kir'yanova, 1979).

In tests of inmobilization of ash from the incineration of sewage sludge (containing cadmium, lead, and chromium), slag cements were found to be superior in suppressing the dissolution of heavy metal ions from the hardened material and also had superior compressive strengths (Kawashima, et al, 1976). Sludges from coal combustion (flyash and desulfurization gypsum) were used as a cementing matrix for phosphate-rich sewage sludge and a solidified material was obtained that reduced the amount of phosphate leaching from the sewage sludge significantly (Akers Consulting Services, Ltd., 1977). A special cement containing ettringite and calcium silicates was found to fix very high amounts of mercury, cadmium, lead, chromium, arsenic, and cyanide (Uchikawa, 1978). Some fixation of heavy metals in cement mixtures is also found to be a characterization of precipitation as heavy metals hydroxides by the calcium hydroxide in the cement (Asano and Konishi, 1978). 
Both flyash and bottom ash composition will vary with the original ash composition of the coal that was burned. Typical bulk flyash and bottom ash compositions from the Four Corners Generation Plant are shown in Table 1 (Roffman, et al, 1977). These same authors give the concentrations of trace elements in the coal, bottom ash, and fly ash. Trace element contents and enrichment ratios for bottom ash and flue gas desulfurization sludge have been published (National Academy of Science, 1980). In a study of flyash from New Zealand coals, the composition of both acid soluble and acid insoluble fractions vere determined (Bibby, 1977). The principle acid soluble fraction consists primarily of alkali components of the ash, especially calcium and boron. Distribution (and concentration) of elements in bottom ash, flyash, and flue gas has also been calculated (Schsitzgebel, et al, 1975; U.S. Environmental Protection Agency, 1975) and the average trace element content of ash from coals in different regions of the United States has also been tabulated (Abernethy, et al, 1969).

\section{Research Objectives:}

The objectives of the proposed research were to find optimum mixtures of flyash, bottom ash, and flue gas desulfurization sludge (DSG) that could be hardened through a pozzolanic reaction into a flyash or ettringite cement that will have high strength and low leachability of heavy metals. The specific goals of this study were: (1) to study the hardness of mixtures of flyash, bottom ash, and DSG treated with lime and other hardening agents; (2) to determine the optimum solids content, setting time, moisture content, and posi setting treatients that will yield the greatest strength and hardness out of these mixtures; and (3) to determine the leachability of the synthetic material as a measure of its ability to retain absorbed and/or entrained toxic metals. 
TABLE 1

Composition of Coal, Bottom and Flyash

\section{Constituent}

$\mathrm{Al}_{2} \mathrm{O}_{3}$

$\mathrm{SiO}_{2}$

MgO

$\mathrm{Fe}_{2} \mathrm{O}_{3}$

$\mathrm{Na}_{2} \mathrm{O}$

$\mathrm{K}_{2} \mathrm{O}$

$\mathrm{CaO}$

$\mathrm{iiO}_{2}$

Ignition Loss

Ash
Major and Minor Constituents ( $\%$ ) Coal

3.0

5.7

0.08

0.55

0.22

0.15

0.72

0.19

11.2
4.5

1. 5

3.3
Bottom Ash

26.2

59.1

0.6

3.9

1.3

0.93

5.0

1.4

1.2 


\section{Materials and Methods:}

Flyash, bottom ash, and DSG from Ohio Edison, flyash and bottom ash from the White Bluff Power Plant of Arkansas Power and Light, and flyash from a Tennessee Valley Authority powf: plant were obtained. These samples provided waste materials from high sulfur Eastern coal, low sulfur Western coal, and an intermediace mix, respectively.

The DSG slurry was decanted and the settled solids scooped out of the bucket and placed in an oven where they were dried at approximately $60^{\circ} \mathrm{C}$ for 48 hours. This resulted in a norous, blocky material which could be ground very rapidly in a pulverizer. The resulting lightweight powder had +95 percent passing a 100 mesh screen. The bottom ash was also dried at less than $60^{\circ} \mathrm{C}$, crushed to $-2 \mathrm{~mm}$, and then passed through a pulverizer and reduced to +80 percent passing a 100 mesh screen. The flyash was already -100 mesh and no further crushing or grinding was performed on it. After drying and pulverizing, the samples were stored in buckets until they were ready for mixing with the hardening agents.

Hardening Tests:

An initial set of 120 tests of hardening agents using mixtures of lime, lime plus calcium chloride, lime plus aluninum sulfate, lime plus aluminum sulfate plus sodium silicate in combination with flyash, bottom ash, and DSG and mixtures of Ohio Edison flyash, bottom ash, and DSG were carried out. Tests of water slurries of USG. flyash, and bottom ash indicated the following $\mathrm{pH}$ :

$\begin{array}{ll}\text { DSG } & 8.80 \\ \text { Flyash } & 3.00 \\ \text { Bottom Ash } & 7.58\end{array}$

The weights of flyash, DSG, and bottom ash and hardening agents used in the 1.20 tests are given in Appendix $A$. 
The dry ground flyash, DSG, and bottom ash were mixed with the powdered chemical reagents and placed in ziplock bags. They were thoroughly mixed by shaking the powdered components together. Between 50 and $100 \mathrm{ml}$ of distilled. water was then added to each bag until a plastic slurry was achieved. The amount of water added varied depending on the content of DSG, with less water being required for the somewhat coarser bottom ash and for the relatively non-absorbent flyash. The bags were then sealed and placed in boxes to harden at room temperature.

The results of the initial hardening tests were somewhat disappointing. After 24 hours, only the flyash and bottom ash and mixtures thereof had shown any significant haxdening. Mixtures containing DSG remained in a plastic or semihardened state. At the end of one week, some additional hardening had taken place but the DSG continued to act as an inhibitor to the hardening process.

The initial hardening tests indicated that the DSG tended to act as a hardening inhibitor rather than an accelerator. This problem was traced to a very low calcium sulfate content and very high calcium sulfite content of the material. The solubility of calcium sulfate is 0.209 grams per $100 \mathrm{cc}$ of water whereas the solubility of calcium sulfite is only 0.0043 grams per $100 \mathrm{cc}$ of water. This low solubility inhibits the conversion of the sulfite to sulfate in the reacting products and inhibits the growth of ettringite.

The second ard subsequent hardening tests contained added calcium sulfate dihydrate so that ettringite would be able to form rapidly during the initial hydration and acted as a cement to hold the calcium sulfite together until its delayed reaction could take place.

Fresh coal flyash and bottom ash was ground to -300 mesh and riew mixes for hardening tests (based on the initial hardening tests) were prepared (Appendix B). The mixes were allowed to harden for one month and were then removed from 
the sample cups and subjected to crushing tests. A subsumple of the material was retained for cation exchange capacity testing.

Expansion aric contraction of the mixes during hardening led to cracking of che test samples (Appendix $C$ ). While some mixtures had excellent hardness, they were relatively low strength because of this cracking.

The original mixes were not pulverized beyond -100 mesh and had strengths ranging from $6.3 \mathrm{~kg} / \mathrm{cm}^{2}$ to $96.4 \mathrm{~kg} / \mathrm{cm}^{2}$ (Table 2). All but one of the unground tests had strengths below $30 \mathrm{~kg} / \mathrm{cm}^{2}$. After grinding to -300 mesh there was a significant increase in strength in all but one case (Table 3).

Chemical Analysis:

Chemical analyses of the fly and bottom ast from Ohio Edison were provided by the Company. Chemical, physical and EP toxicity tests are reported in Tables 4-6.

Mineralogical Analysis of Flyash and Hardened Products:

Examination of air dried DSG, flyash and pulverized bottom ash was carried out using packed powder mounts on an $x$-ray diffractometer. The DSG consists entirely of calcium sulfite dihydrate and does not appear to contain any gypsum (Figure $1 \mathrm{a}$ and $1 \mathrm{~b}$ ). The bottom ash revealed only glassy phases; however, tne flyash contained distinct peaks for quartz, mullite, and hematite (Figure 2).

Examination of the reaction products indicated the formation of ettringite, calcium monosulfate hydrate, an unknown hydrated phase, and minor calcite, A mix of 1 part flyash and 1 part bottom ash to 5 parts DSG treated with $10 \%$ lime showed distinct formation of ettringite, a very minot formation of a hydrated unknown phase, and furmation of calcite (Figure 3 ). The same mix ratio treated with $10 \%$ lime and calcium chloride as a hardening accelerator showed the complete disappearance of the ettringite peak and essentially no formation of calcite. 


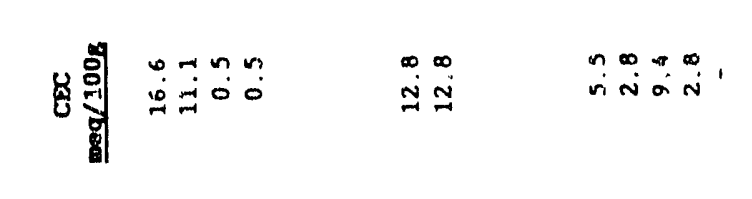

\begin{tabular}{|c|c|c|c|}
\hline & 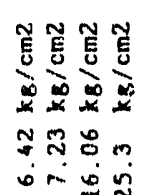 & 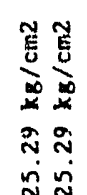 & 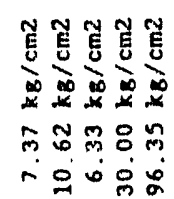 \\
\hline
\end{tabular}

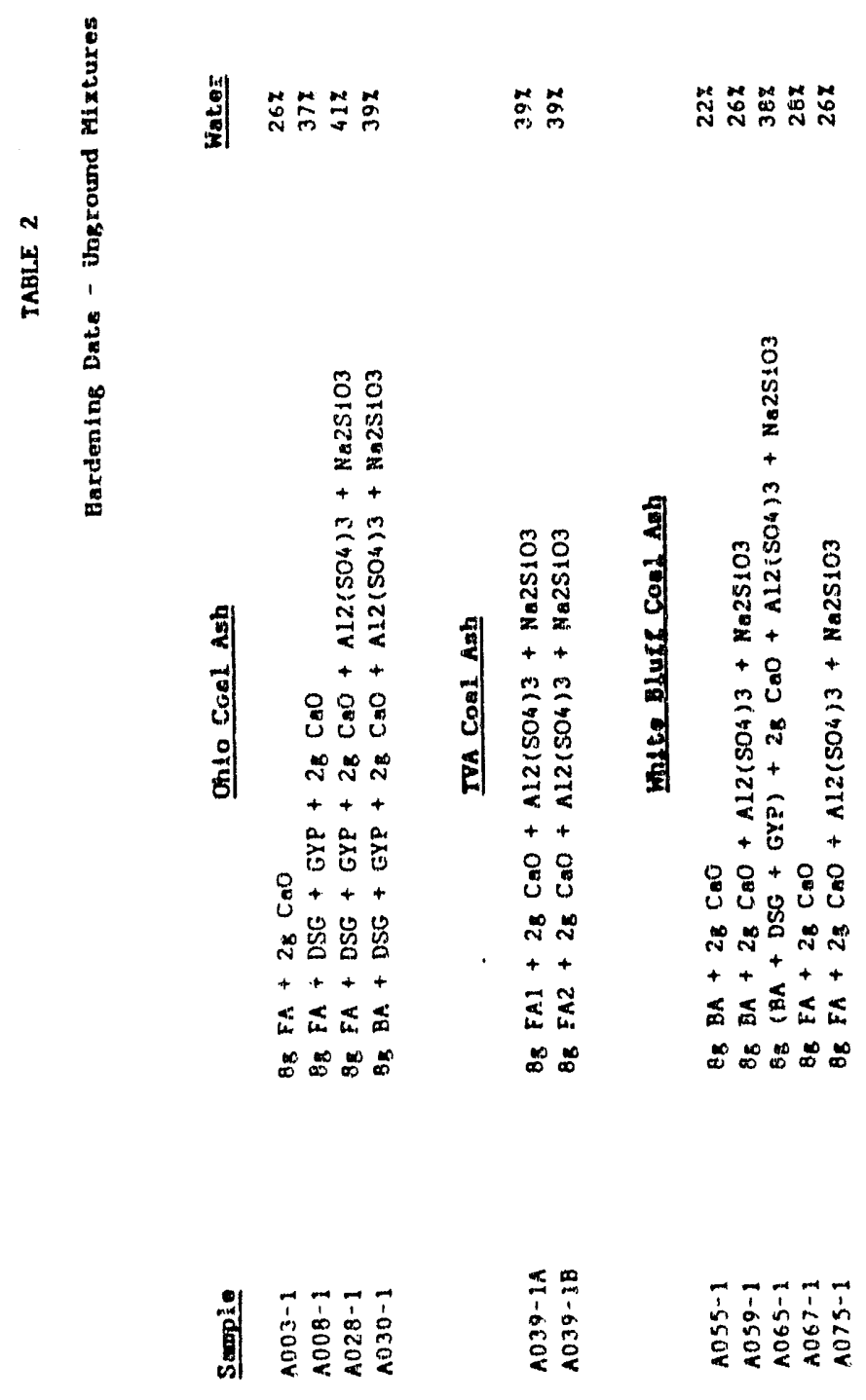



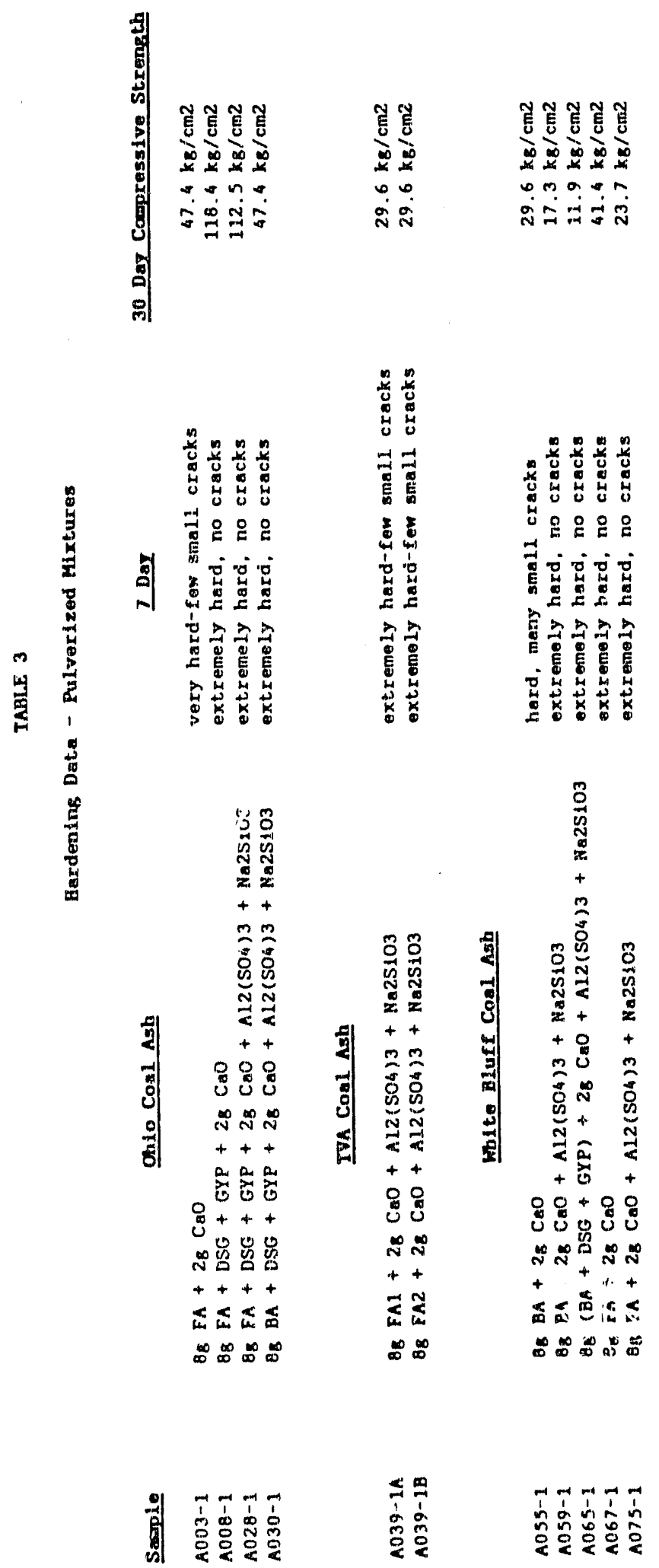


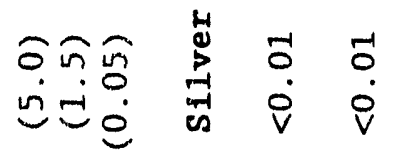

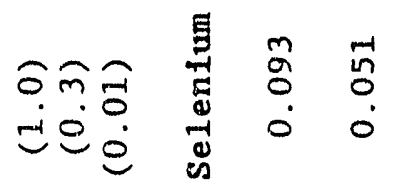

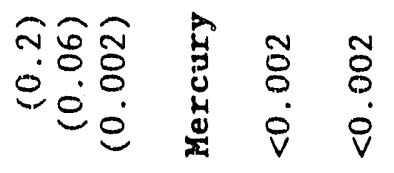

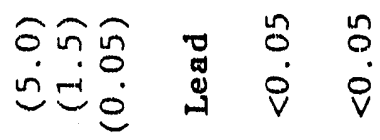

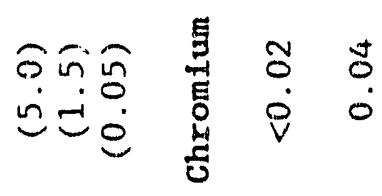

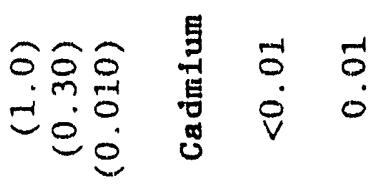

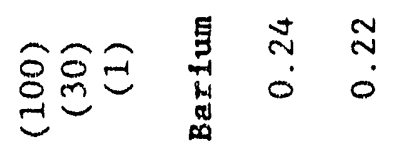

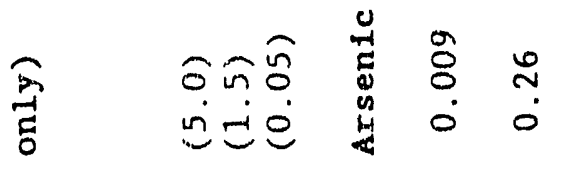

$$
\begin{aligned}
& \frac{\pi}{\infty}
\end{aligned}
$$

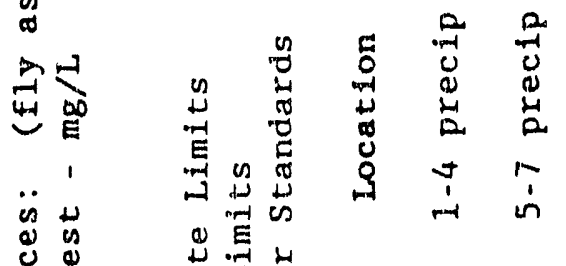

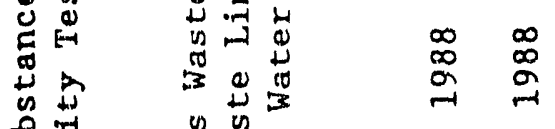

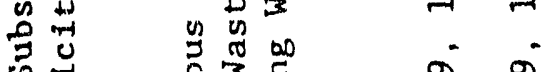

$$
\begin{aligned}
& \text { 的藏 }
\end{aligned}
$$

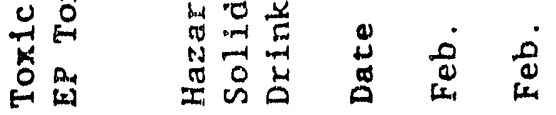




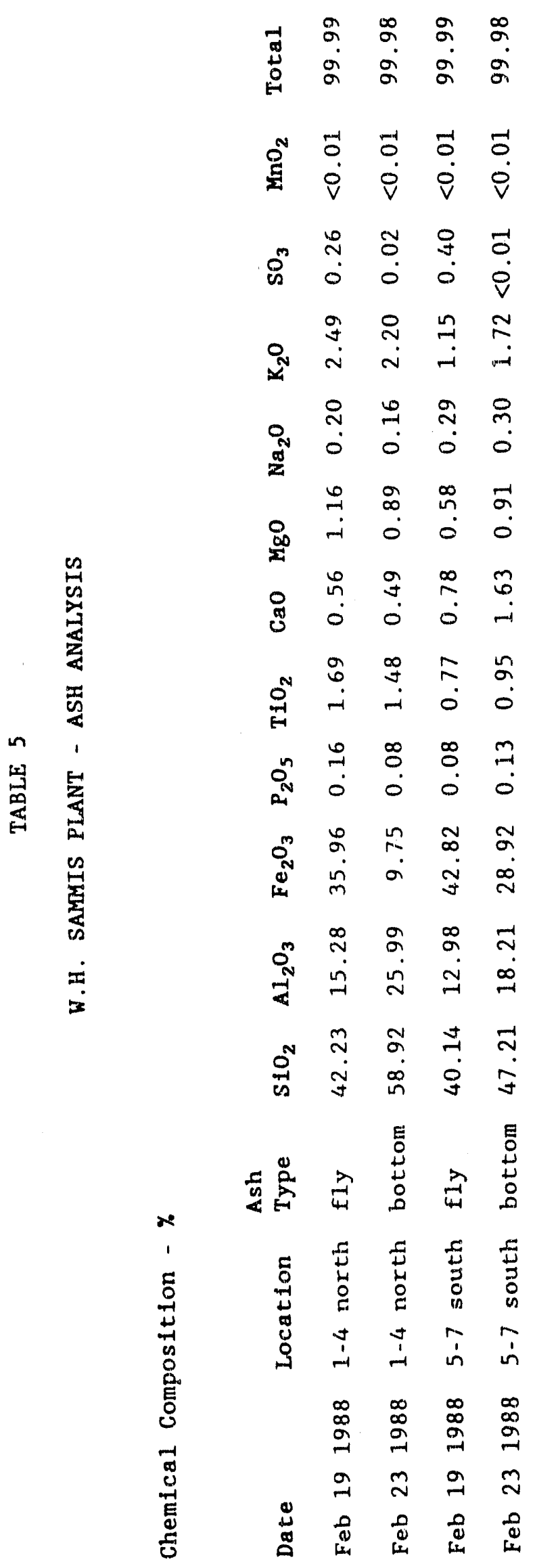




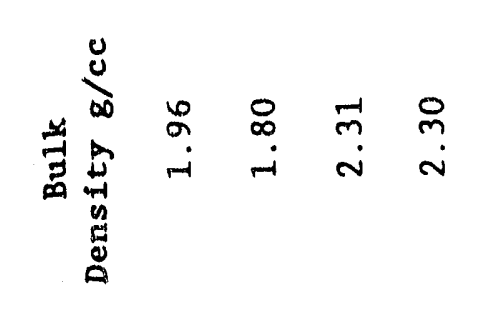

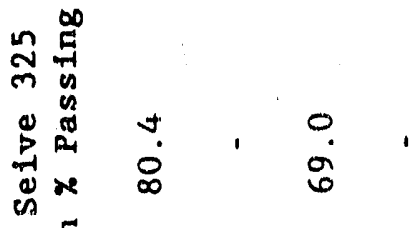

$$
\begin{aligned}
& \text { 山 }
\end{aligned}
$$

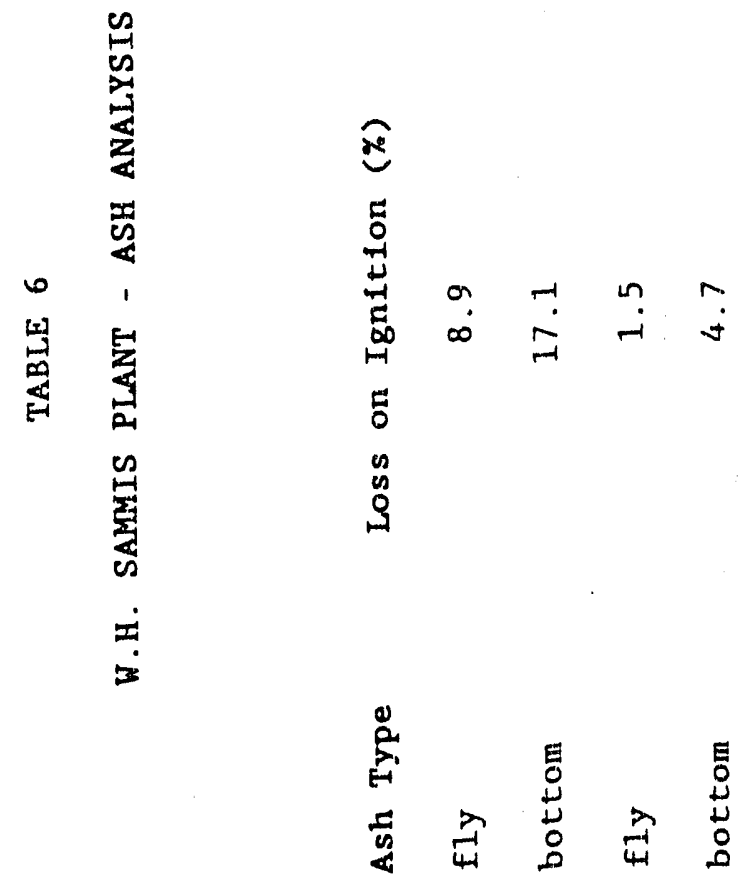

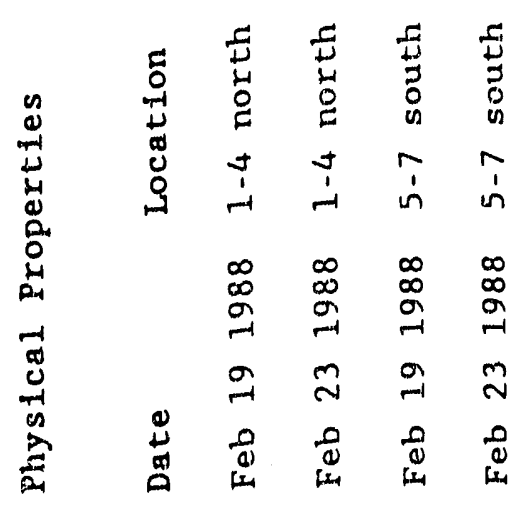




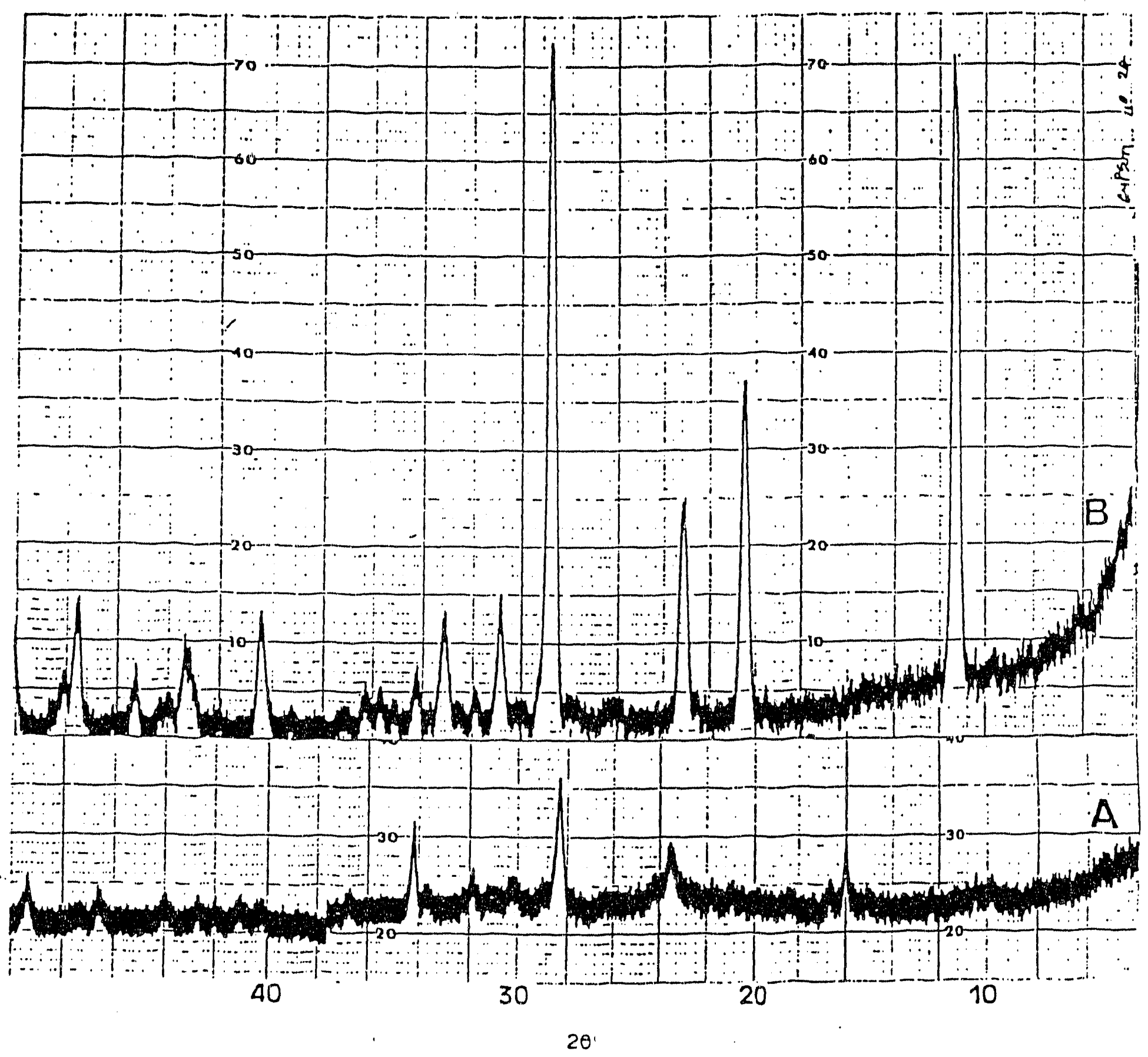

Figure 1. (A) Air dried desulfurization gypsum sludge. Packed powder mount, CuKa. Specimen is essentially pure $\mathrm{CaSO}_{3} \cdot 2 \mathrm{H}_{2} \mathrm{O}$. (B) Cypsum, $\mathrm{CaSO} \cdot 2 \mathrm{H}_{2} \mathrm{O}$ reference specimen. Same conditions as A. 


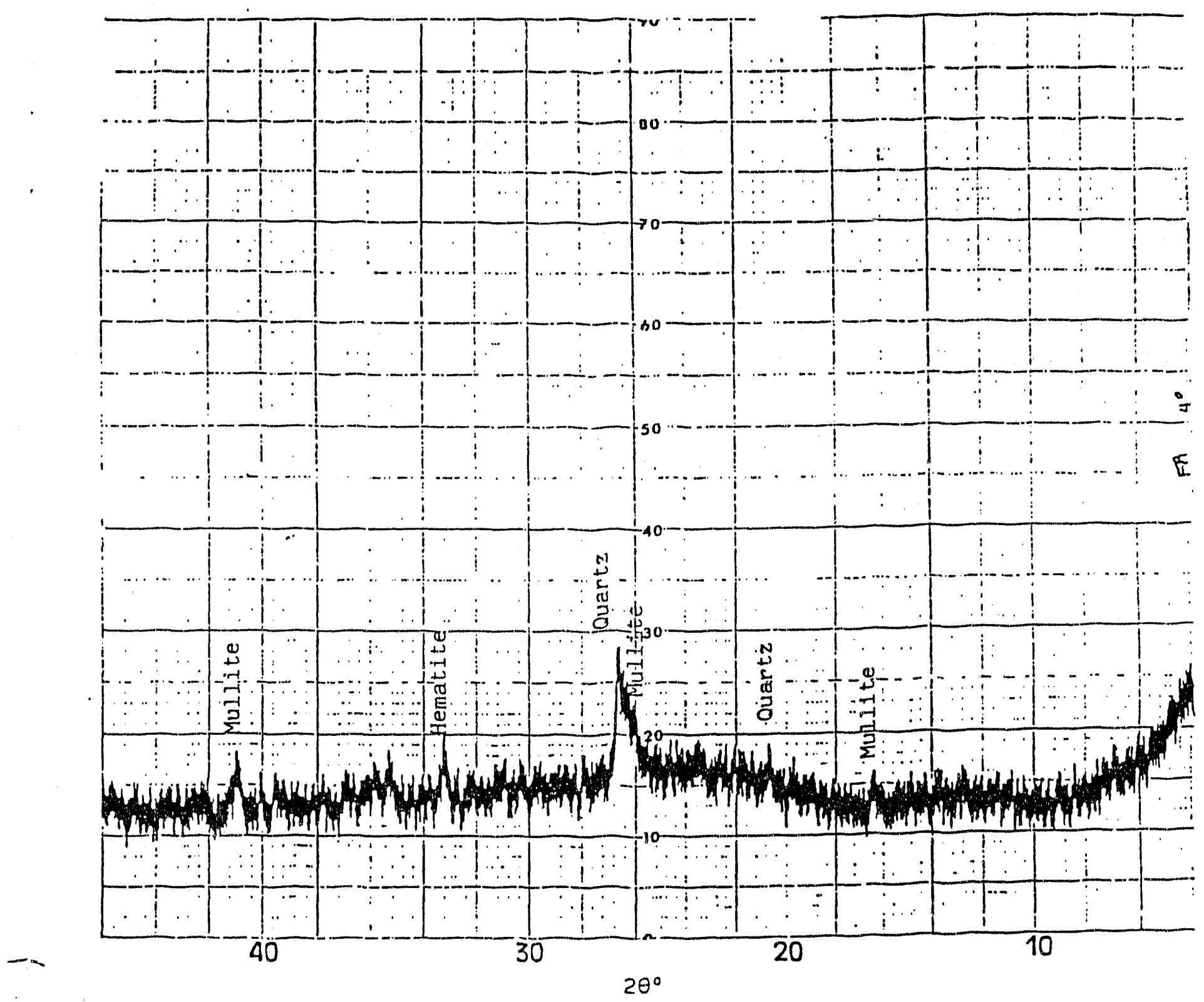

Figure 2. Packed powder mount of rlyash, Cukco. Peaks for crystalline phases of mullite, quartz, and heinatite are indicated. 


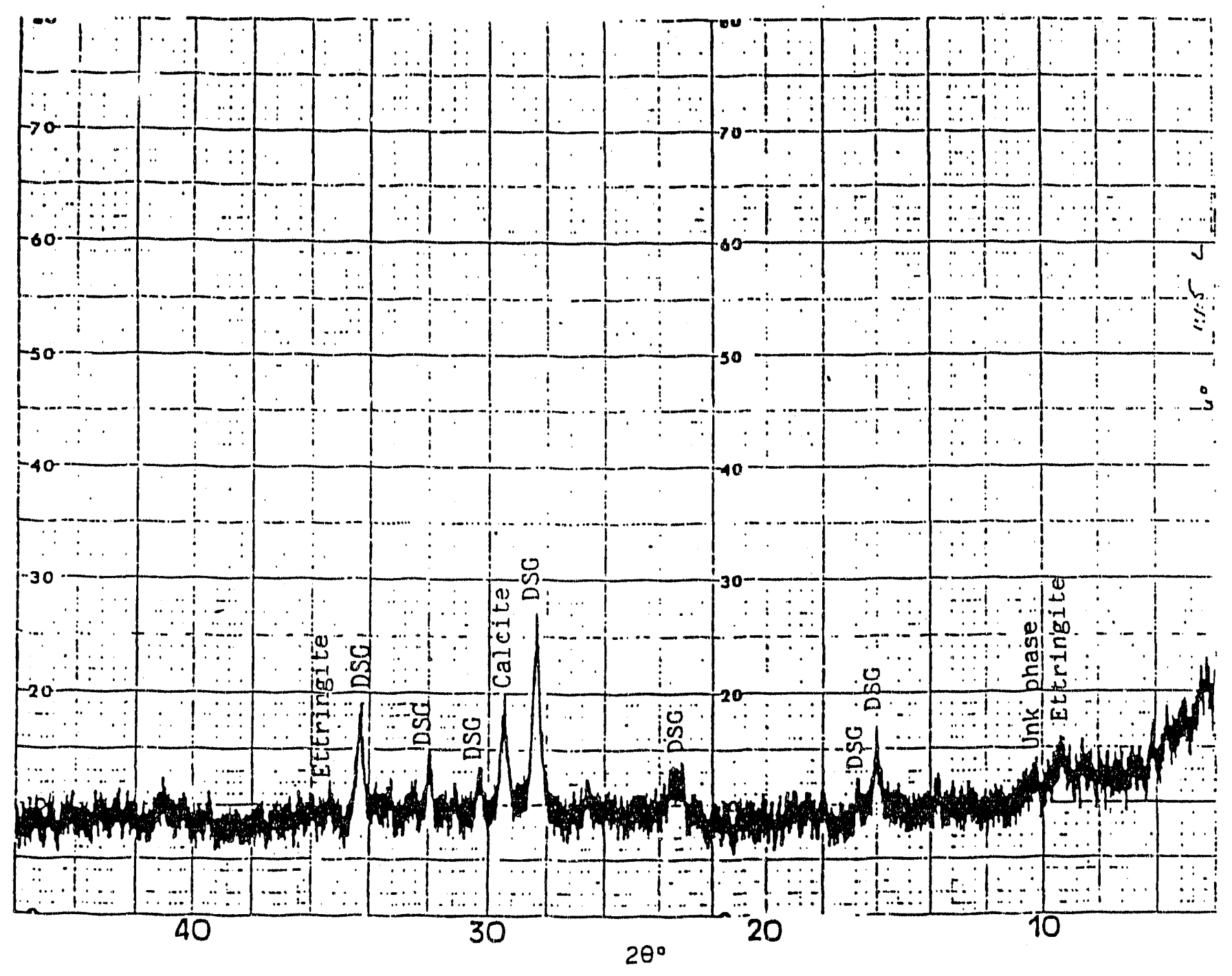

Figure 3. 1 part flyash, 1 part bottom ash (pulverized) and 5 parts desulfurization gypsum sludge (DSG) reacted with $10 \%$ lime. Silide mount, CuKo. Peaks assignable to reaction products are indicated. 
The suppressing action of calcium chloride in the formation of these minerals has not been reported previously, although calcium chloride is known to be an accelerator in concrete setting (Figure 4).

The addition of $10 \%$ lime plus aluminum sulfate to the test mix generated the greatest anount of ettringite and some minor monosulfate and calcite (Figure 5). Addition of lime, aluninum sulfate, and sodium sulfate as hardeners to the same mix generated considerably less ettringite but also generated monosulfate, an unknown hydrated phase, and some calcite (Figure 6). It is possible that some tobermorite phases were generated; however, these could not be detected. A number of unsuccessful attempts were made to synthesize pure ettringite and calcium monosulfate hydrate; however, the mixtures obtained were always contaminated with either calcite or gypsum as reaction products. A literature review of the synthesis of these components has been conducted and an attempt will be made to generate pure reference materials for later work.

Cation Exchange Capacity (CEC) of the Hardened Ash Mixtures:

The CEC of the hardened mixtures was determined using ammonium absorption and measuring the retained ammonium with an ammonia specific ion electrode. This technique is simple, rapid, and essentially free of interferences. The CEC's of various hardening mixtures are given in Appendix D. CEC's ranged from 0.5 meq/100 g to $16.6 \mathrm{meq} / 100 \mathrm{~g}$. For comparison purposes, a montmorillonitic clay has a CEC that is typically $110 \mathrm{meq} / 100 \mathrm{~g}$. The relatively low CEC of these mixtures is thought to reflect the relatively small amount of cation exchanger generated as hardening agents. If for example, only $10 \%$ of ettringite or torbermorite were generated during hardening and this $10 \%$ component represented all of the cation exchanger, then the CEC's reported would actually be fairly high on a unit weight basis. Further testing of mixes with higher ratios of ettringite and torbermorite will be needed to determine the true CEC of the 


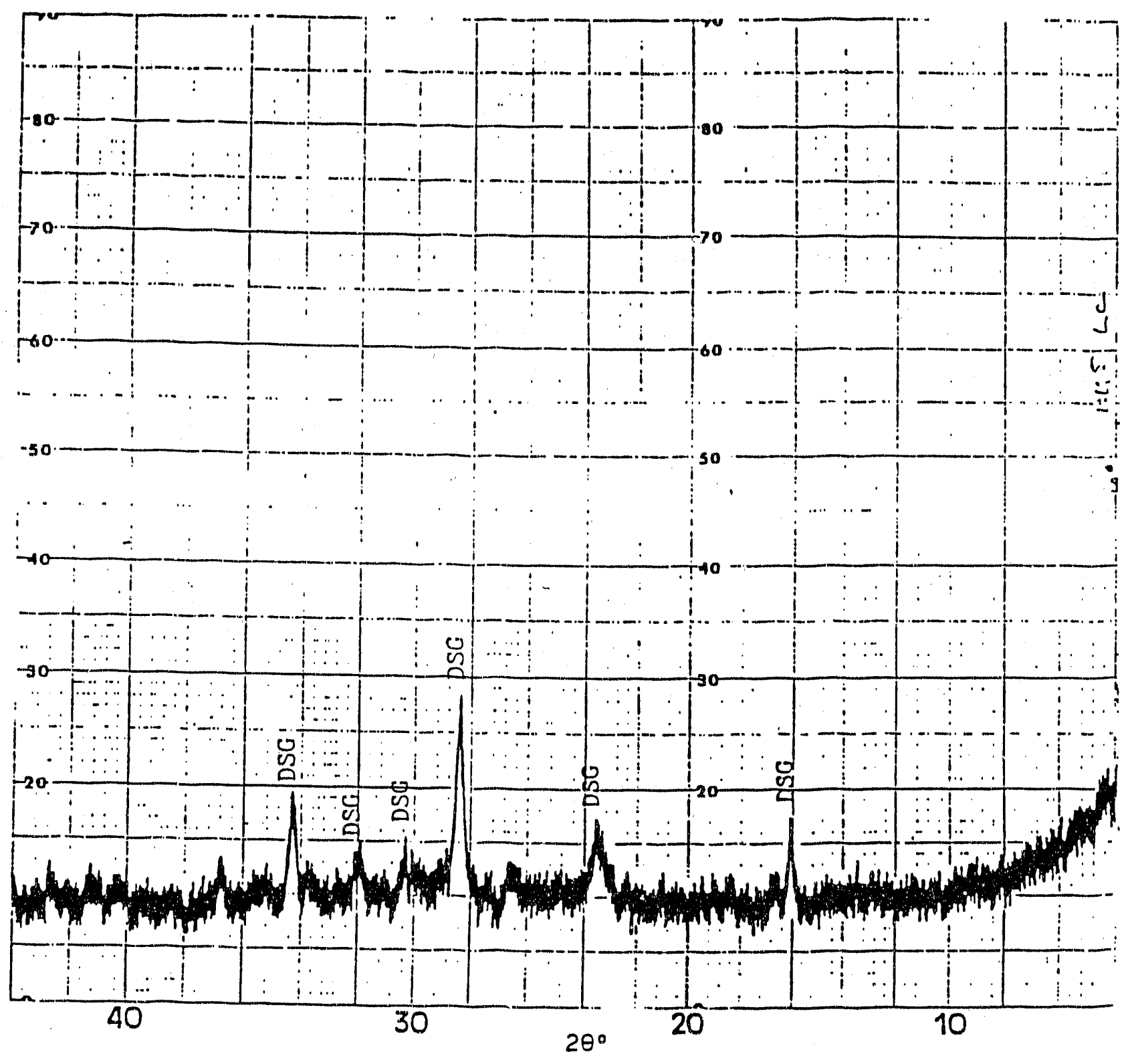

Figure 4. 1 part flyash, 1 part bottom ash (pulverizedi and 5 parts desulfurization Bypsum (DSG) reacted with $10 \%$ Ilme plus $\mathrm{CaCl}_{2}$ accelerator. Slide mount, CuKoc. Note the absence of reaction products. 


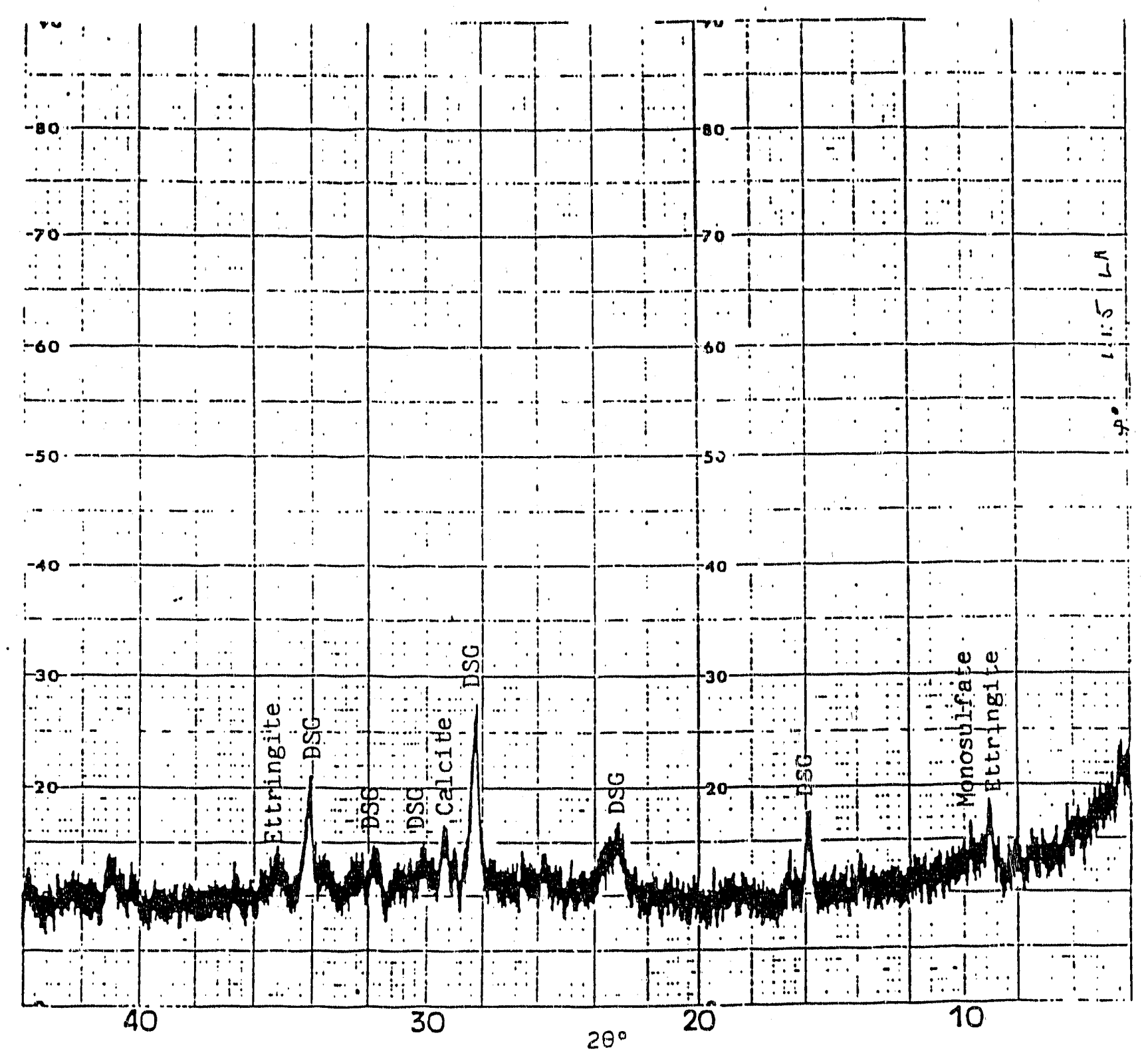

Figure 5. 1 part flyash, 1 part bottom ash (pulverized) and 5 parts desulfurization gypsum (DSG) reacted with $10 \%$ lime and $\mathrm{Al}\left(\mathrm{SO}_{4}\right)_{3}$ accelerator. Slide mount, CuKor. Peaks for reaction products are indicated on the diffractogram. Note the apparent presence of calcium monosulfate hydrate. 


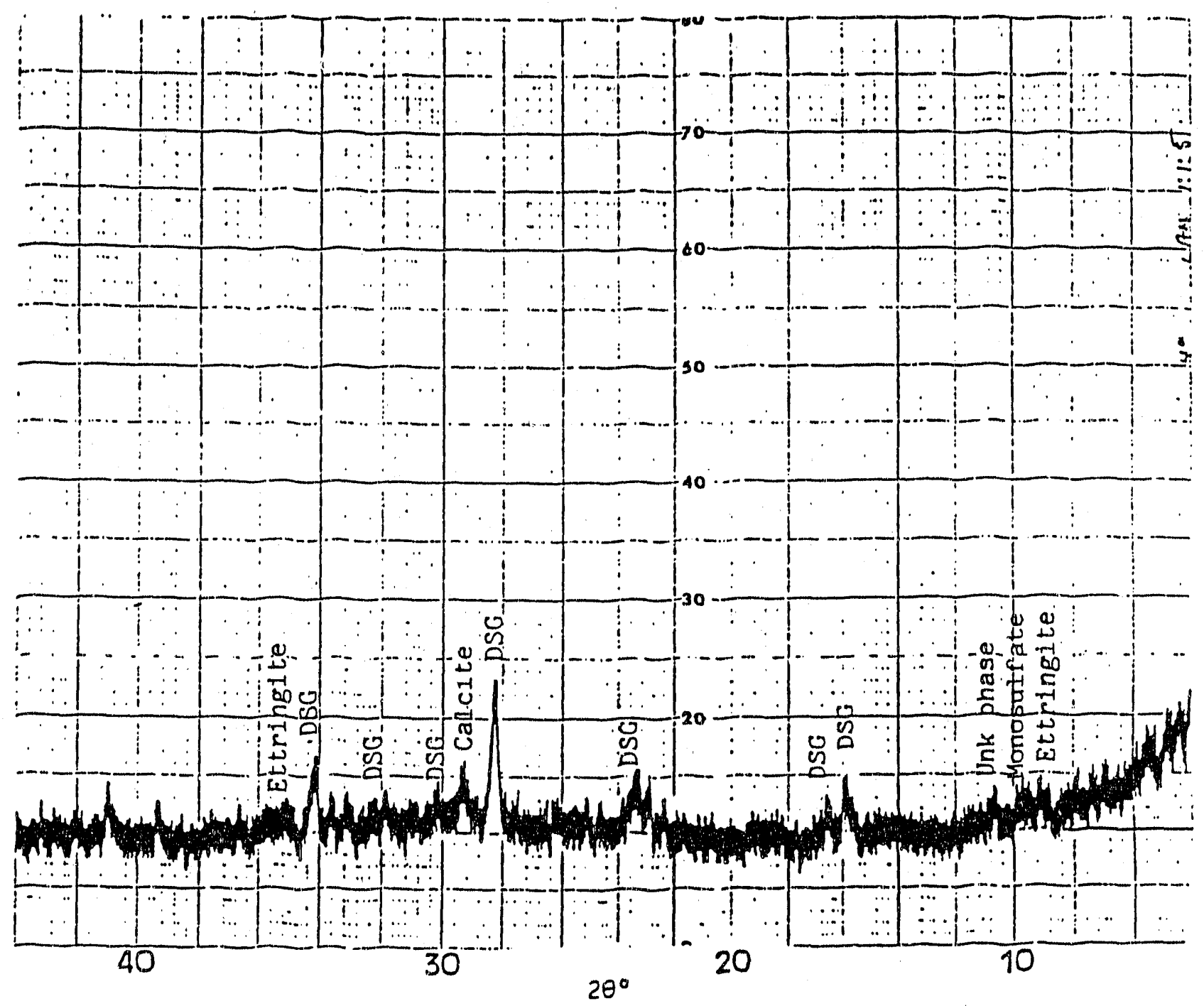

Figure 6. 1 part flyash, 1 part bottom ash (pulverized), and 5 parts desulfurization gypsum (DSG) reacted with $10 \%$ lime and $\mathrm{Al}_{2}\left(\mathrm{SO}_{4}\right)$ and sodium silicate accelerators. Slide mount, CuK $\propto$. Reaction products are indicated on the difrractogram. Note the presence of an unidentified hydrous phase and calcium monosulfate hydrate. 
hardening agents. Selectivity of the hardening agents is unknown at this time and will be tested during the leaching phase.

\section{XRF Analysis of Heavy Metal Sorption Capacity:}

Stock solutions containing 10,50, and $100 \mathrm{ppm}$ of $\mathrm{As}, \mathrm{Co}, \mathrm{Cu}, \mathrm{Ni}, \mathrm{Se}, \mathrm{Zn}$, and $\mathrm{Hg}$ were prepared from $1000 \mathrm{ppm}$ standard solutions supplied by Chemical Manufacturing Co., Gardenia, California, and by Alpha Analytical Labs, Newark, New Jersey. These standards were in a matrix of dilute $\mathrm{HCl}$ and $\mathrm{HNO}_{3}$. The $\mathrm{pH}$ of the solutions was:

$\begin{array}{rl}10 \mathrm{ppm} & 2.50 \\ 50 \mathrm{ppm} & 1.80 \\ 100 \mathrm{ppm} & 1.60\end{array}$

These pH's roflect the acid matrix of the standards. Fifty ml of the stock solution was equilibrated for 1 hour with $1 \mathrm{~g}$ of crushed, hardened mixture. Approximately $5 \mathrm{ml}$ of the equilibrated solution was poured into an XRF cup, covered with $0.25 \mathrm{mil}$ mylar film and analyzed in a Norelco XRF spectrograph. Analytical lines and settings used are in Table 7.

All analyses were performed using a scintillation detector and a count time of 100 seconds.

Calculation of concentration was from standards after subtraction of background courits. Detection limits were below 30 ppm on the elements analyzed.

Results of the sorption tests are reported in Figures 7-15 and Appendix E. In general, the anions $A$ s and Se were lightly adsorped. $\mathrm{Zn}$ and $\mathrm{Cu}$ were variable but demonstrated intermediate adsorption. Hg was also variabie but tended to be highly adsorbed. Only $\mathrm{CO}$ and $\mathrm{Ni}$ were adsorbed completely at all treatment levels.

There was some desorption at higher treatment levels, especially for As and Se. This was probably caused by the higher acidity of the solution used to sorb the heavy metals on the hardened material (see Table 8). Much of the adsorption 


\section{TABLE 7}

Aralytical Lines and Settings for

XRF Analysis of Heavy Metal Sorption

\section{ELEMENT}

As

Co

$\mathrm{Cu}$

$\mathrm{Pb}$

$\mathrm{Ni}$

Se

W

$\mathrm{Zn}$

$\mathrm{Hg}$ $\underline{\lambda}$

1.177

1.790

1.542

1.1 .75 (La)

1.659

1.106

1.479

1.436

1.24 (Le)
If F Analyzer Setting $\left(2 \theta^{\circ}\right)$

34.00

52.79

45.03

33.93

48.66

31.89

43.02

41.80

35.90 
TABIE 8

$\mathrm{pH}$ of Metal Adsorption Tests

$\begin{array}{cccc}\text { Sample No. } & 10 \text { ppm } & \text { 50 ppm } & 100 \mathrm{ppm} \\ \mathrm{A} 003-1 & 11.4 & 10.2 & 1.5 \\ \mathrm{~A} 008-1 & 11.5 & 9.0 & 1.4 \\ \mathrm{~A} 028-1 & 9.4 & 4.1 & 1.5 \\ \mathrm{~A} 030-1 & 11.2 & 3.9 & 1.6 \\ \mathrm{~A} 055-1 & 11.2 & 10.0 & 3.9 \\ \mathrm{~A} 059-1 & 10.8 & 7.5 & 3.4 \\ \mathrm{~A} 065-1 & 11.0 & 6.8 & 3.1 \\ \mathrm{~A} 067-1 & 11.2 & 10.5 & 4.3 \\ \mathrm{~A} 075-1 & 10.2 & 8.7 & 4.2\end{array}$




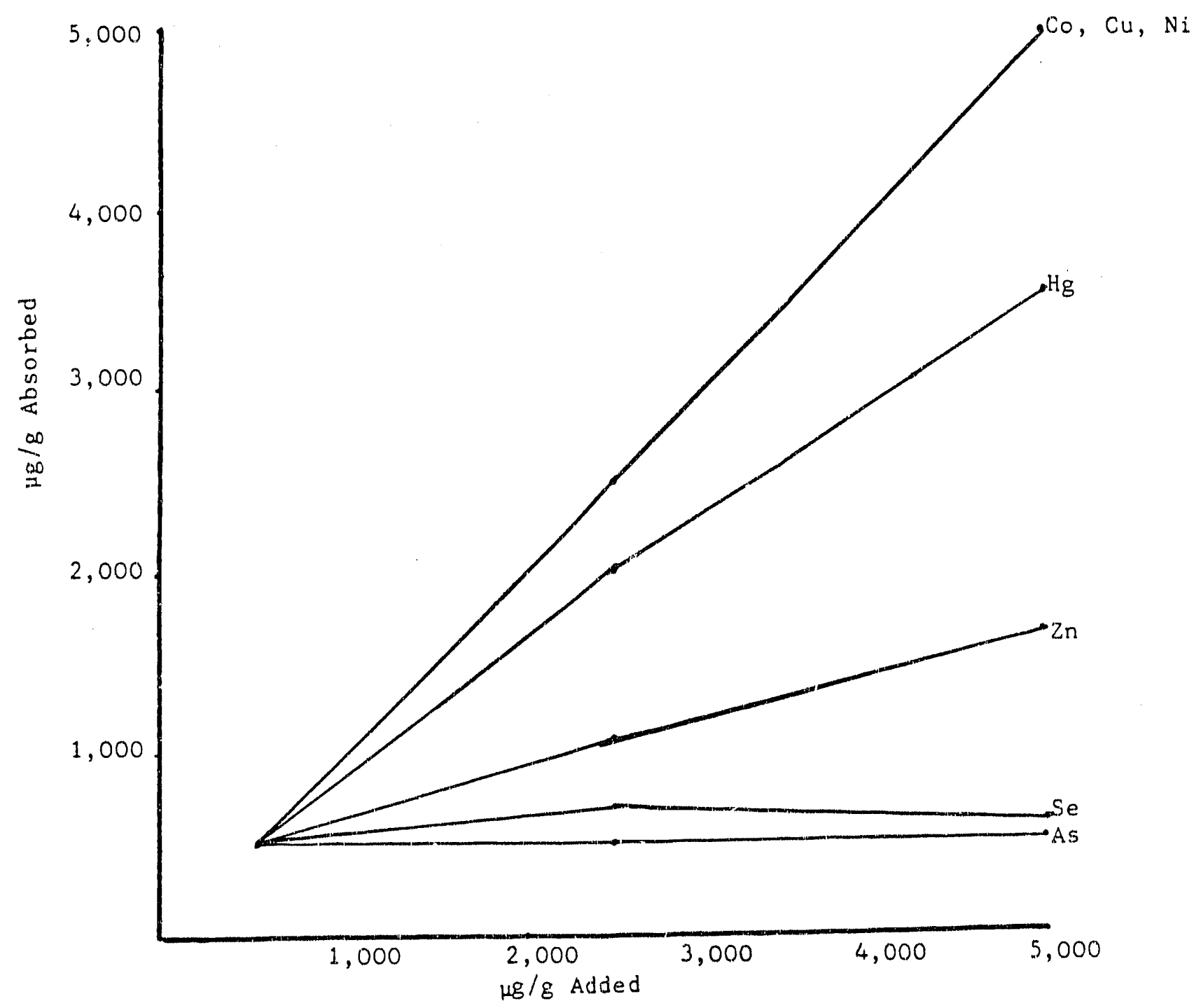

Figure 7. Absorbtion of heavy metals on hardened mixture A003-1. 8g FA + $2 \mathrm{~g} \mathrm{CaO}$ 


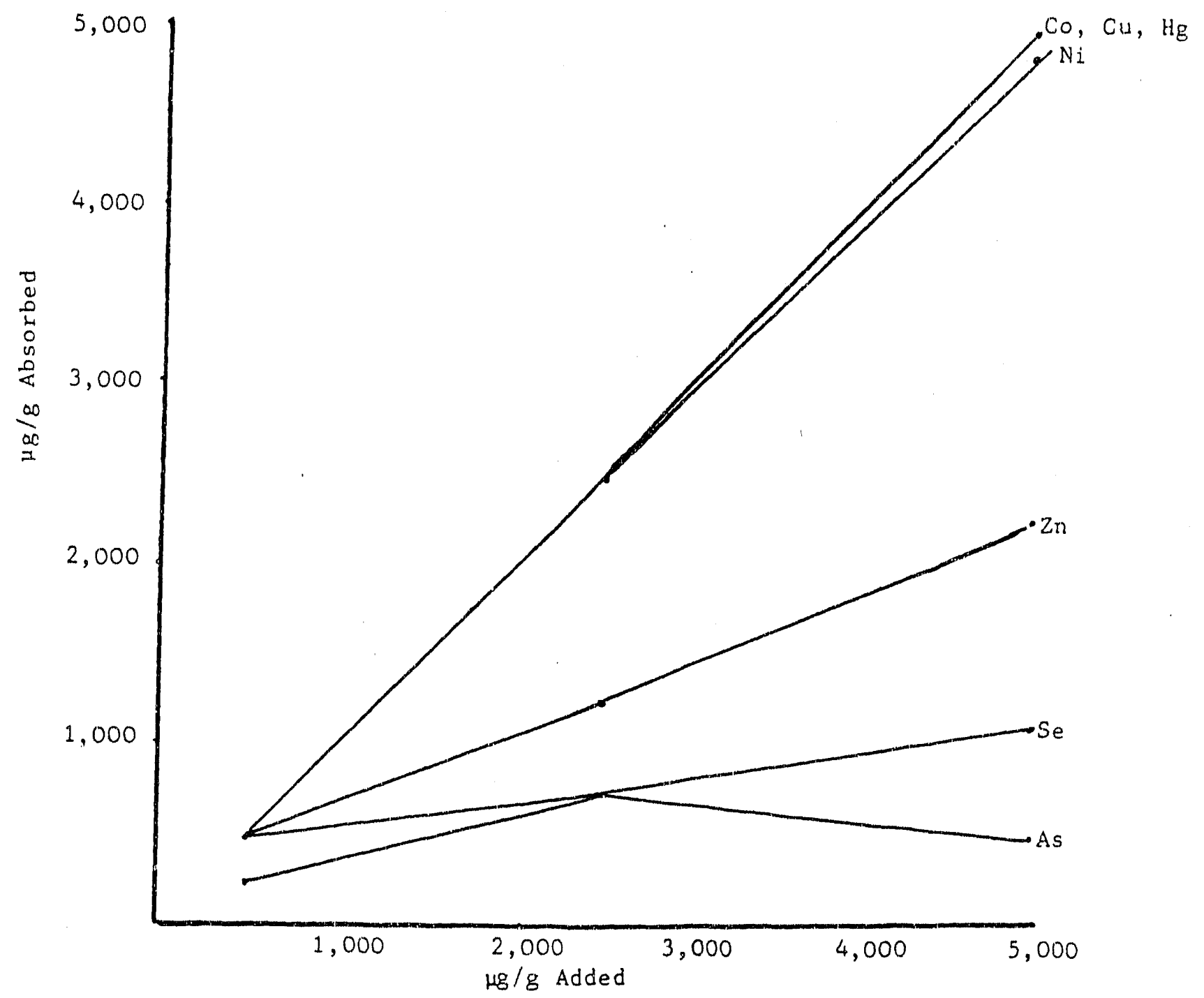

Figure 8. Adsorption of heavy metals on hardened mixture A008-1. $8 \mathrm{gFA}+\mathrm{DSG}+\mathrm{GYP}+2 \mathrm{gCaO}$ 


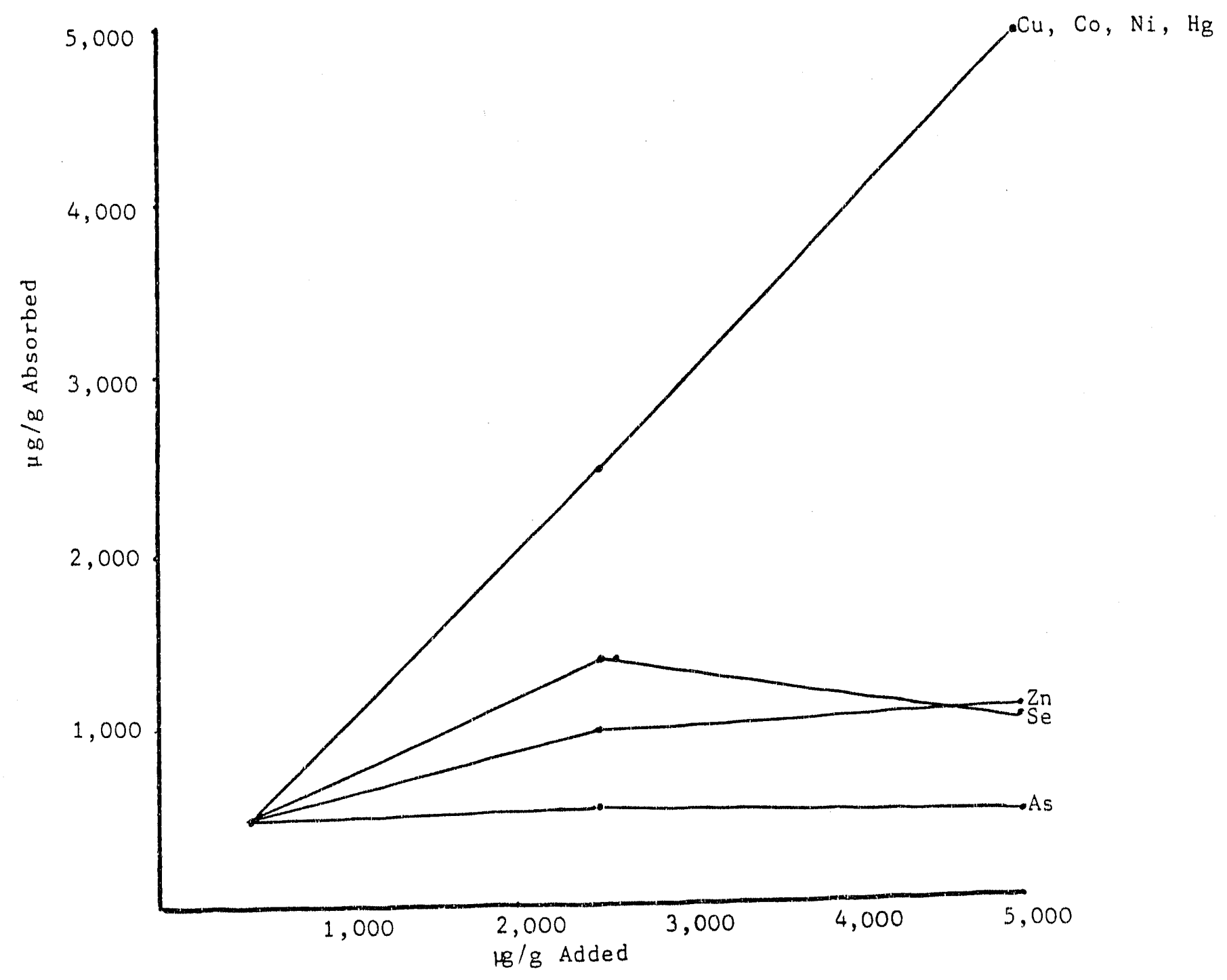

Figure9. Adsorption of heavy metals on hardened mixture AO28-1. $8 \mathrm{gFA}+\mathrm{DSG}+\mathrm{GYP}+2 \mathrm{~g}\left[\mathrm{CaO}+\mathrm{Al}_{2}\left(\mathrm{SO}_{4}\right)_{3}+\mathrm{Na}_{2} \mathrm{SiO}_{3}\right]$ 


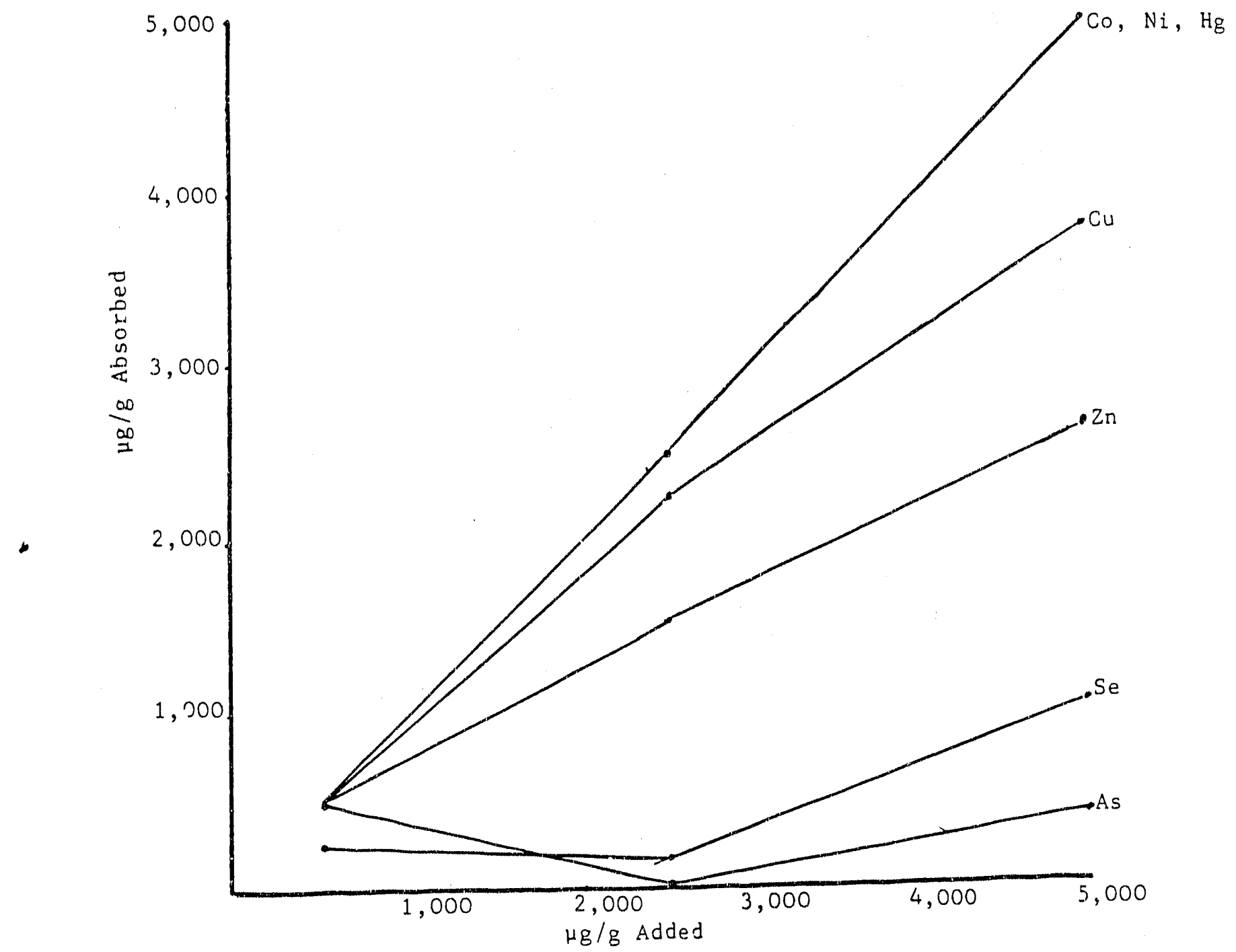

Figure 10. Adsorption of heavy metals on hardened mixture A030-1. $8 \mathrm{gBA}+\mathrm{DSG}+\mathrm{GYP}+2 \mathrm{~g}\left[\mathrm{CaO}+\mathrm{Al}_{2}\left(\mathrm{SO}_{4}\right)_{3}+\mathrm{Na}_{2} \mathrm{SiO}_{3}\right]$ 


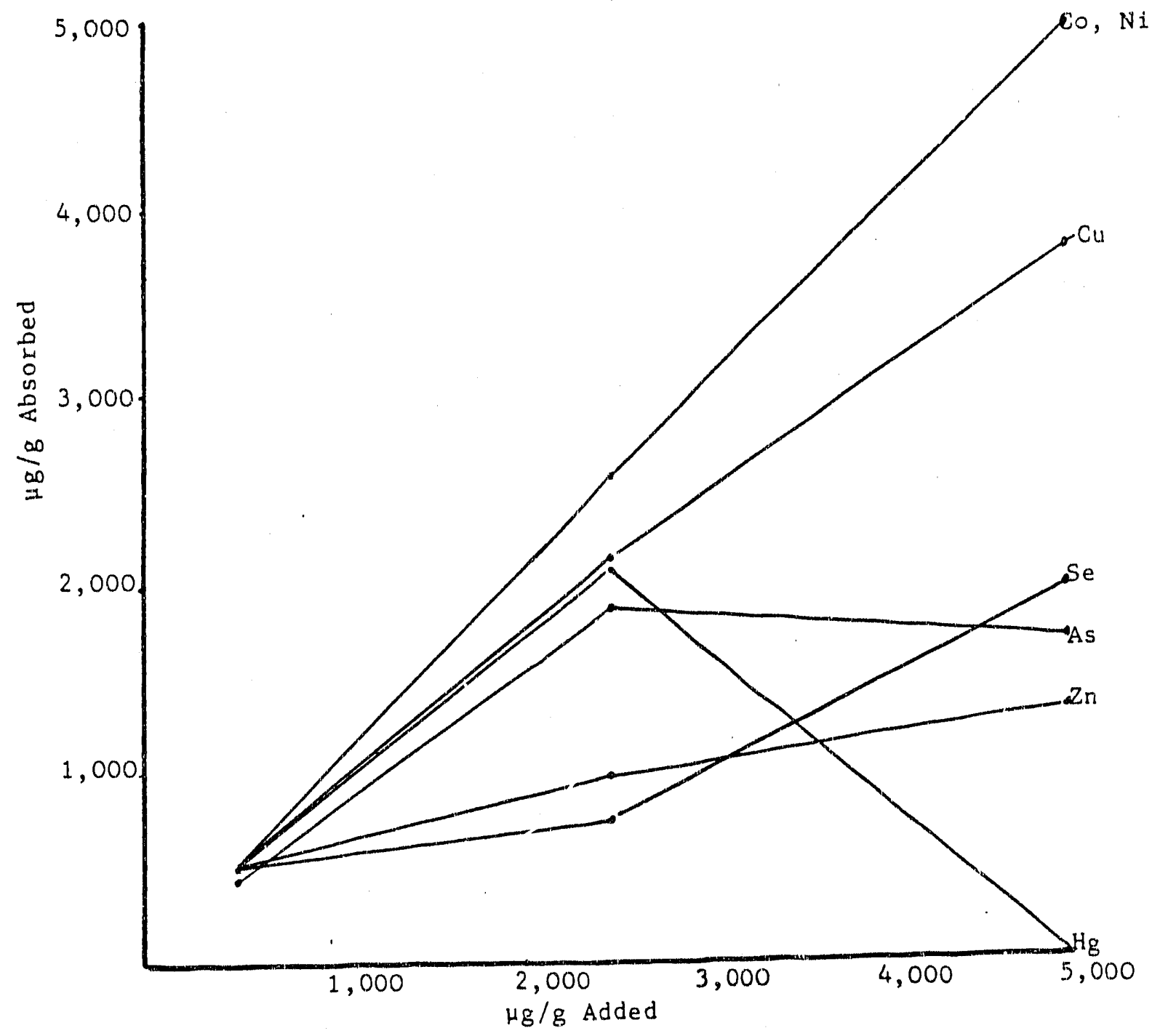

Figure 11. Adsorption of heavy metals on hardened material A055-1. $8 \mathrm{~g} \mathrm{BA}+2 \mathrm{~g} \mathrm{CaO}$. (Hg value is probably anomalous) 


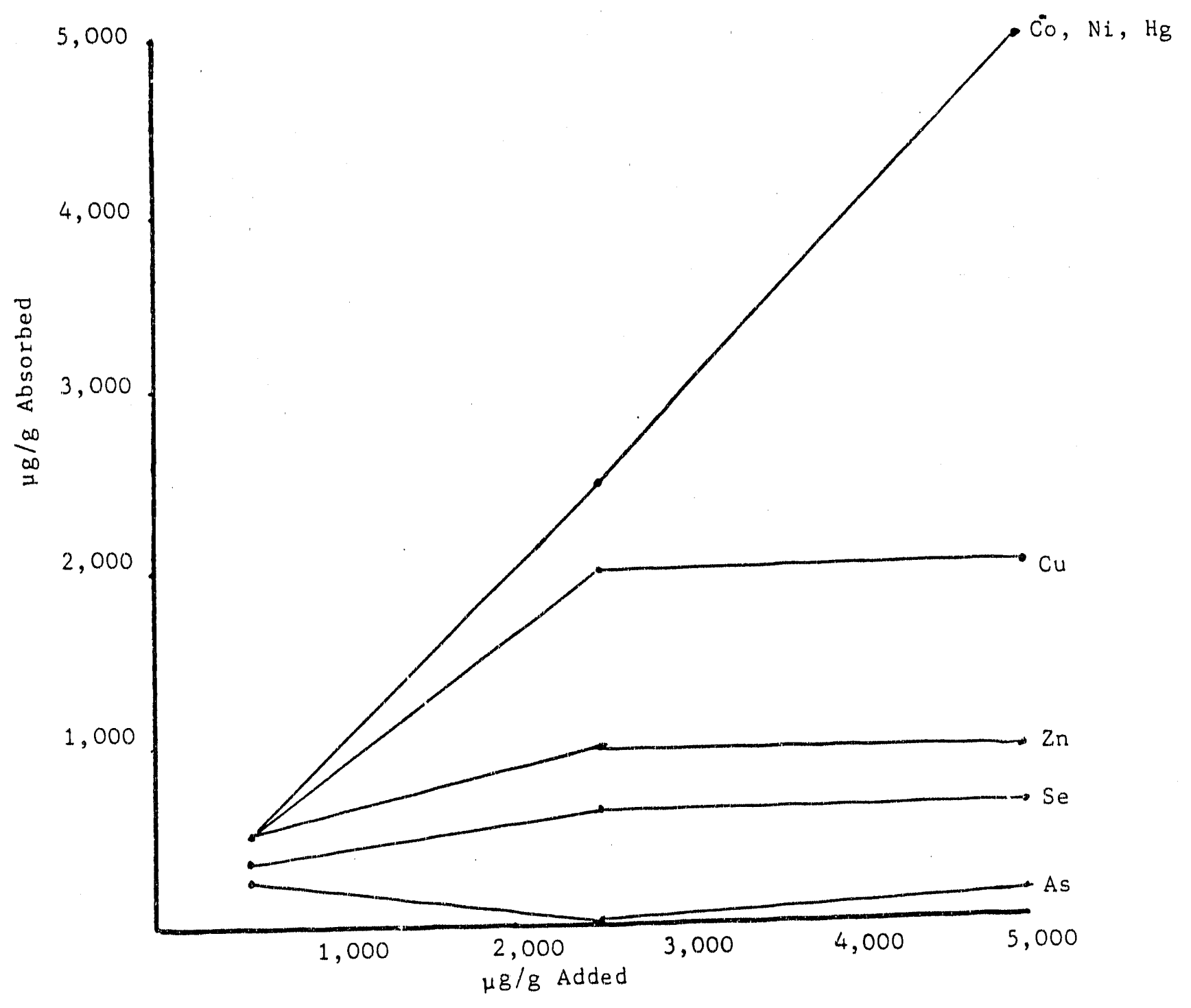

Figure 12. Adsorption of heavy metals on hardened material A059-1. $8 \mathrm{gBA}+2 \mathrm{~g}\left[\mathrm{CaO}+\mathrm{Al}_{2}\left(\mathrm{SO}_{4}\right)_{3}+\mathrm{Na}_{2} \mathrm{SiO}_{3}\right]$ 


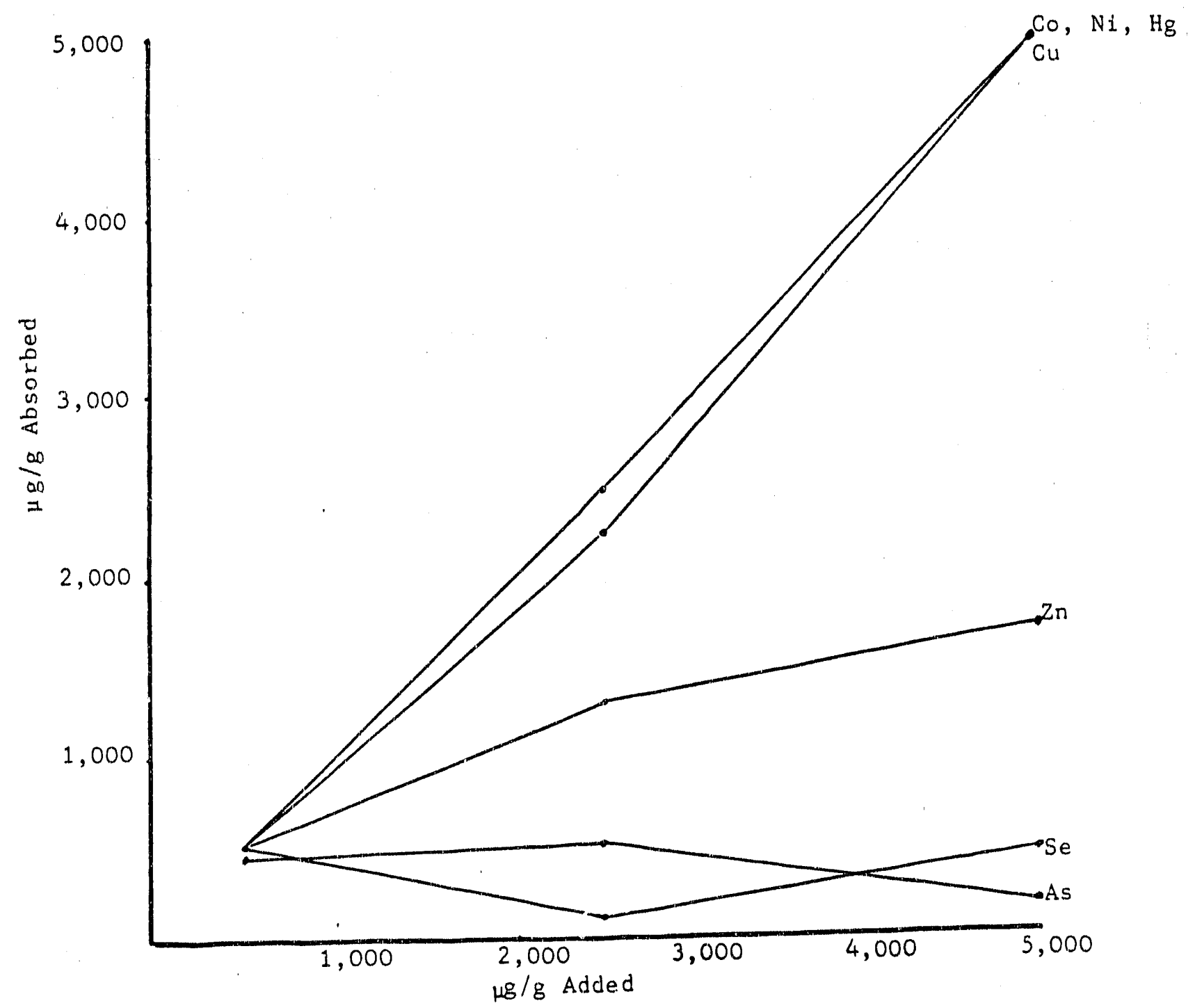

Figure'13. Adsorption of heavy metals on hardened material A065-1. $8 g(\mathrm{BA}+\mathrm{DSG}+\mathrm{GYP})+2 \mathrm{~g}\left[\mathrm{CaO}+\mathrm{Al}_{2}\left(\mathrm{SO}_{4}\right)_{3}+\mathrm{Na}_{2} \mathrm{SiO}_{3}\right]$ 


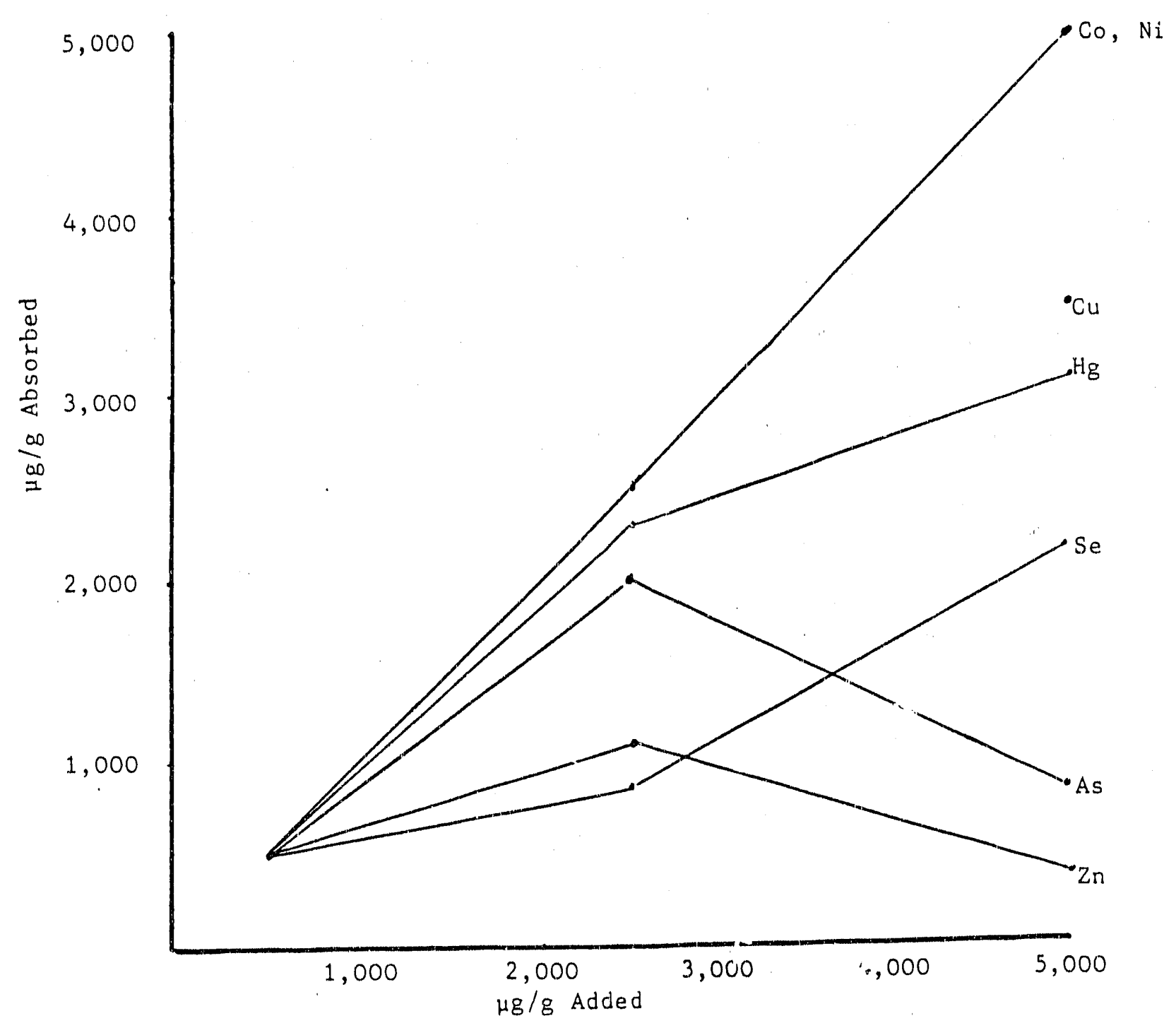

Figdre 14. Adsorption of heavy metals on hardened material A067-1. $8 \mathrm{gFA}+2 \mathrm{~g} \mathrm{CaO}$ 


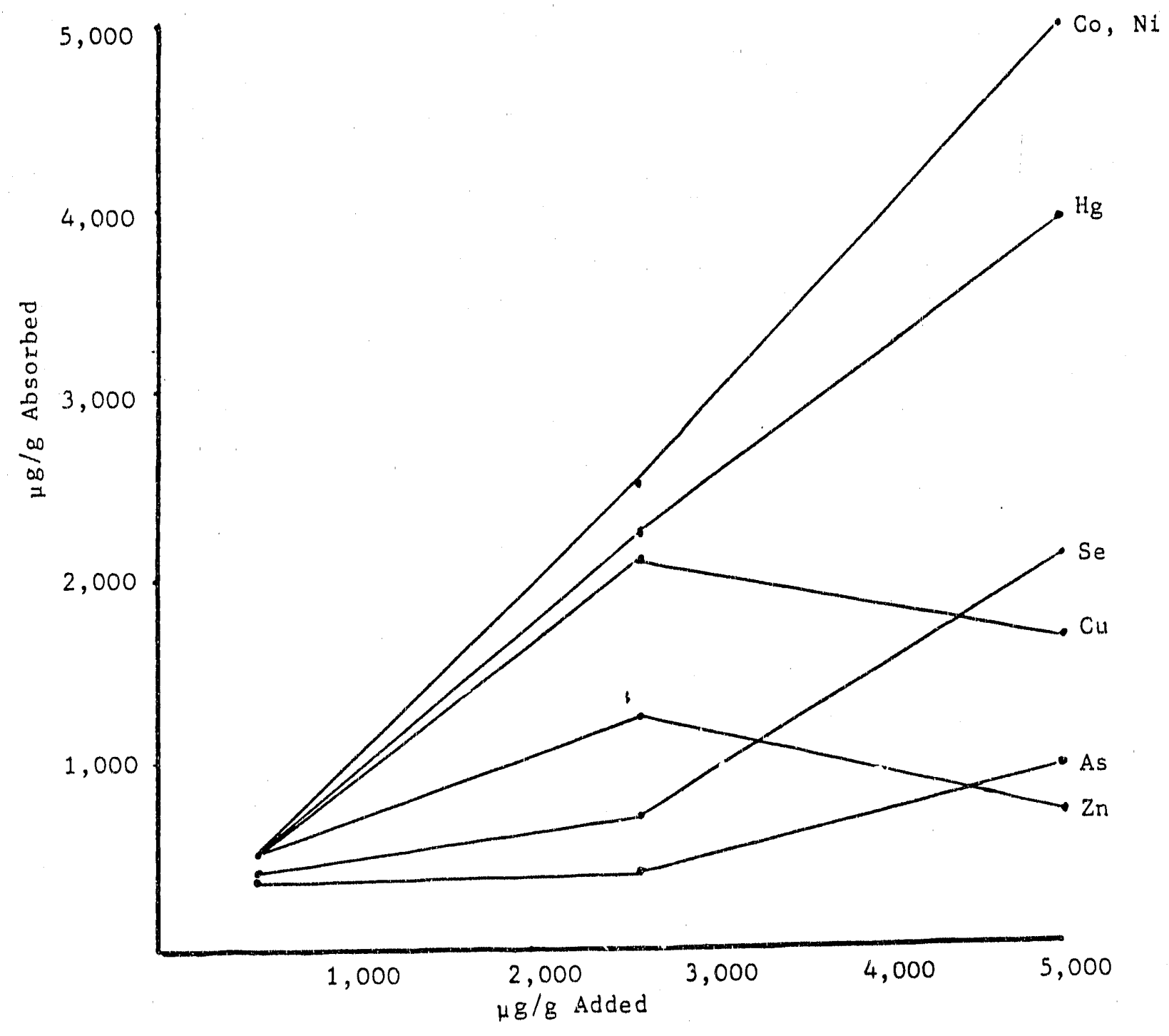

Figure 15. Adsorption of heavy metals on hardened material A075-1. $8 \mathrm{~g} F A+2 g\left[\mathrm{CaO}+\mathrm{Al}_{2}\left(\mathrm{SO}_{4}\right)_{3}+\mathrm{Na}_{2} \mathrm{SiO}_{3}\right]$ 
may be attributed to a precipitation reaction caused by the alkalinity of the hardened materials.

\section{Results and Discussions:}

The hardness tests provided satisfactory evidence that cementing agents (including torbermorite and ettringite) can be generated in flyash, bottom ash, and desulfurization sludge. The degree of cementation is dependent on several factors including (1) fineness (surface area) of the ash and DSG; (2) uniformity of mixing of the hardening agents; (3) moisture content of the mix; (4) formation of carbonates during drying cycles; and (5) the degree of cracking caused by formation of shrink-swell components (mostly ettringites). The amount of shrinkswell appears to control the strength (but not the hardness) of the mix. Many samples that crumbled before testing produced granules that were quite hard and crush resistant.

Strengths of unpulverized mixtures ranged from 0 to $96 \mathrm{~kg} / \mathrm{cm}^{2}$. Strengths for pulverized mixes ranged from 11 to $118 \mathrm{~kg} / \mathrm{cm}^{2}$. This compares well with ranges of such mixes reported previously in the literature. Various forms of heat treating are known to generate compressive strengths up to $400 \mathrm{~kg} / \mathrm{cm}^{2}$ in such mixes; however, for simple air-curing the values are typically clustered around $100 \mathrm{~kg} / \mathrm{cm}^{2}$.

Cation exchangers were generated during hardening; however, the percentage of these materials in the hardened product was relatively low. CEC's ranged from $0.5 \mathrm{meq} / 100 \mathrm{~g}$ to $16.6 \mathrm{meq} / 100 \mathrm{~g}$.

Adsorption tests of heavy metals has demonstrated that the hardened materials have excess capacity to adsorb heavy metals. This demonstrates that under worst case conditions (high acidity) the hardened raterials are stable and would not release toxins to the environment. 
This project has demonstrated that diverse mixtures of coal-fired power plant wastes can be hardened satisfactorily. The problem of cracking of the mixtures will have to be overcome befou structural use of the hardened products can be realized. For simple disposal, such as road underlayment, the hardened product should be more than adequate. 


\section{REF LRENCES}

Abernethy, R.F., Peterson, M.J., and Gibson, F.H., 1969, Spectrochemical arialysis of coal ash for trace elements, U.S. Bur. Mines, Rep). Invest.. $7281,30 \mathrm{p}$.

Abyzov, A.N.: Kir'yanova, L.A., 1979, Porous aluminophosphate binders and lightweight heat-resistant concretes made from them. Stroit. Mater. Izdeliyo Osn. Otkhodov Prom. Proizvod., Vermikulita Poputnykh prod., $79-82$.

Acres Consulting Services, Ltd., 1977, Reuse of waste sulfur dioxide and phosphate sewage sludges by solidification with line and fly ash. Res. Rep.-Res. Program Abalement Munic. Pollul. Provis. Can.- Ont. Agreement Great Lakes Water Qual., 69, 22 pp.

Asano, Shunkichi; Konishi, Humito, 1978, Fixation of heavy metal inns in the early stage of hydralion on cement. Semenlos Gijutsu Nenpo, 32: 78-81.

Baselsen, Svend., 1979, Hardening composition. üpn. Kokai Tokkjo Koho, 79 58,726

Bibby, D.M., 1977, Composition and variation of pulverized fuel ash obtained from the combustion of sub-bituminous coals, New Zealand, Fuel, 56: 427.

Bucklen, O.D., Cockrell, C.F. Donahue, B.A., Leonard, J.W., McPadden, C.R., Meikle, P.G., Mih, L.i, and Shafer, H.E., 1965, Coal associated ininerals of the U.S., part 7: Uses, specifications and processes related io coal-associated minerals, RDR-8(7), Coal Research Bureau, National Technical Information Service, Springfield, Va., PB-168, $116 \mathrm{p}$.

Caspar, Jean Pierre; Gaillard, Jacques, 1980, Ettringite fibers. Can. $1,079,480$.

Chudo, Akira; Sugi, Tomomit.su. Kaianka, Koji; Yanagihara, Hirohiko; Komatsu, Shigehiro; Ando, Yutaka, 1978, Ettringite. Japan. Kokai 78 32,900.

Faber, J.H., Babcock, A.W., and Spencer, J.D., Eds., 1976, Proceedings 4th International Ash Utilization Symposium, St. Louis, ERDh Report, CONF760322 .

Fujiko, K.K., 1980, High-strength soil hardening by grout injection. Jpn. Toikyo Koho 8021,131 .

Gacesa, Tea; Mehmedagic, Stanka, 1976, Chemicai method for determination of ettringite. Cement. (Zagreb), 19:63-7.

Grzymek, Jerzy; Malolepszy, Jan, 1973, Binding materials made from calcareous fly ash, carbide residue, and quicklime. Zesz. Nauk. Akad., Gorn.-Hutn., Cracow, Zesz. Spec., 49, 17-21.

Hasaba, Shigemasi. Torii, Kazuyuki, 1979, Compressive strength and fatigue characteristics in stabilized soil using flue gas desulfurization byproduct and granulated blast furnace slag. Rev. Gen. Meê., Tech. Sess.-Cem. Assoc., Jpr., 33rd, 330-1. 
Hayashi, Toshio, 1976, Inorganic hardened product. Japan. Kokai $7691,934$.

Ichimura, Masaaki; Ginyama, Isao; Sato, Masao; Tanaka, Hirobumi, 1979, A few experinents for ultra-rapid hardening cementitious material. Rev. Gen. Meet., Tech. Sess.-Cern. Assoc. Jpn., 33: 153-4.

Kanno, Koichi; Higashi. Tomisoburo, 1977, Innrganic hardened product useful as building material. Japan. Kokai $7782,927$.

Kawashima, Chikara; Shishido, Kaoru; Ito, Masatoshi, 1976. Effective use of incinerated ash of seworge slurlge for soil cenent. Semeno Gijutsu Nenpo, 30: $101-4$.

Kana, Hideharu; Fujii, Masanobu; Kuroha, Kenji; Marushima, Norio, 1976, Fire resistance of etiringite admixed gypsum. Taisei Kensetsu Gijutsu Kenkyusho Ho, 9: 13-18.

Kondo, Masakazu; Fujisawa, Akira; Ito, Takeo, 1979, Lightweight composice material. jpn. Tokkyo Koho 79 14,133.

Kondo, Renichi; Fujisawa, Tsuneo, 1974, Ettringite from blast-furnace granulated slag. japan. Kokai $7469,592$.

Kubo, Masaaik: Sedo, Kazun, 1977. Ettringile-based building materials, Japan. Kokai 7793,430 .

Lucas, Walter, 1980, Reaction processes in the fly ash-gypsum/calcium hydroxide mixture. TIT. 104: 630-3.

Mineshita, Yutaka; Azuma, Tonisahuro; IChimaru, Kazuto, 1977, Inorganic composite materials wilh high strength. Japan. Kokai 77, 133,326.

Mineshita, Yutaka; Imai, Akira, 1979, Inorganic hardened product. upn. Kokai Tokkyo Koho 7964,516 .

Mori, Shigejiro; Kitsugi, Kyoichi, 1974, Solidification of hydrous red mud. vapan. Koniai $7969,569$.

Nukhamedbaeva, Z.A.; Acakuziev, T.A.; Tadzhiev, F.Kh., 1972, Possible preparation of unfired iron-loessial cement, Tr. Tashk. Politekh. Insi., 90: $3-4$.

Nlakagawa, Koji: Ontsuka, Telsun; Maejima, Hideo, 1977, Rapid hardening of cement. Japan. Kokai 77,110,724.

National Academy of Science, 1980. Trace Element Geochemistry of Coal Resources Development Related to Environmental quality and Health. National Acadeny Press, Washington D.C.

Witto Chemical Industry Co., Lid., 1980, Soil strengthening. Jpn. Kokai Tokkyo koho 8086,879 . 
Oates, Joseph A.H., 1975, Light-weight, porous building materials containing binders made from lime and silica gel. Ger. Offen. 2,502,319.

Oguri, Yasuo; Hashimi, Fijyio, 1973, Gypsum products from calcined gypsum and dehydrated etcringite. Japan. Kokai 73 103,620.

- Ramanauskiene, L.; Vektaris, B.; Kaminskas, A. Yu.; Mituzas, A., 1978, Method for quantitative determination of free calcium oxide. Siroit. Nater., 8: 3l-2.

Ravina, D., 1979, PFA concrete in South Africa. Pap.-Symp. Util. Pulverized Fuel Ash, Paper No. 16, $11 \mathrm{pp}$.

Roffman, H.K., Kary, R.E., and Hidgins, T., 1977, Ecological distribution of trace elements enitied by coal-burning power generating units employing scrubbers and electrostatic precipitators, Pap. Symp. Coal Util., 4: 192.

Savinkina, M.A.; l.ngvinenko, A.T., 1974, Binders From lignite ashes and slag. Izv. Vyssh. Uchel. Zaved., Stroit, Arkhitekt, 17(5), 78-83.

Schwiczgebel, K., Meserole, F.B., Oldham, R.G., Magee, R.A., Mesich, F.G., and Thoern, T.L., 1975, Trace element discharge from coal-fired power plants, Int. Conf. Heavy liet. Environ., Syinp. Proc., Ist, 2: 533-551.

Simeonov, I.; Dzhabarov, N., 1973, Strength increase of cernent by additional ettringite formation. Zem.-Kalk-Gips, 26: 194-9.

Simeonov, 1.; Dzhabarov, N., 1977, Study of rapid-hardening cements based on clinkers with a phosphogypsuin mineralizer. Fiz-khim, Mekh., 3: 3-14.

Simeonov, I.; Dzhabarov, N., 1978, Improvenent of the qualities of calcium chloride used as an additive accelerating the hardening of coricreie. God. Vissh. Inzh.-Stroit. Inst., 26: 157-70.

Societe des ciments Francais, 1978, Special cemeni for stabilizing road bods. Fr. Deriande 2,391,968.

Spencer, L.L. and L.D. Drake, 1987, llydrogeology of an alkaline fly ash landfill in Eastern lowa., Groundwater 25: 519-526.

Sueddeutsche Kalkstickstoff-Werke A.-G., 1977. Mineral fibers. Fr. Demande $2,351,046$.

U.S. Environmental Protection Agency, 1975, Coal Fired Power Plant Trace Element Study, A Three Station Comparison, Vols. I and 11 , Reports prepared by Radian Corporation, EPA Rocky Mountain Prairie Region VIII.

Uchikawa, H.; Tsukiyama, K., Mihara, Y., 1978, Fixation of harmful elements by a high-grade special cement. Zem.-Kalk-Gips, 31: 195-203.

Uchikawa, H.; Uchida, S., 1974, Analysis of ettringite in hardened cement paste. Cem. Cuncr. Res., 4:821-34. 
Visvesvaraya, H.C., 1978, Routine mineral analysis of portland cement/clinker by XRD using an unmixed internal standard. A monograph. Monogr. MS (Cem. Res. Inst. India), MS2-78, $18 \mathrm{pp}$.

Webster, William C.; Smith, Charles L., 1973, Fly ash-lime cement. Ger. offen. $2,131,161$.

Yamamoto, Chikashi; Shigenatsu, Tatsuhiko; Matsuo, Sachio, 1979, Hardener for strengthening road beds. Jpn. Kokai Tokkyo Koho, 79 91,529. 
APPENDICES 
APPENDIX A

Proportions of Fly Ash, Bottom Ash, and Desulfurization Gypsum (DSG) Sludge and Hardening Agents Used in

Test of Ohio Edison Waste Products. Hardening Results:

$\mathrm{N}=\mathrm{N} 11$ (Plastlc after 1 week), W = Weakly Hardened,

$M=$ Moderately Hardened, $H=$ Hardened (Resists Crushing)

\begin{tabular}{|c|c|c|c|c|c|c|c|}
\hline $\begin{array}{l}\text { Power Plant } \\
\text { By-Product Tested }\end{array}$ & \multicolumn{3}{|c|}{$\begin{array}{l}\text { Lime } \\
\mathrm{Ca}(\mathrm{OH})_{2}\end{array}$} & \multicolumn{3}{|c|}{$\begin{array}{l}1 \text { Part Lime/1 Part Calcium } \\
\qquad \mathrm{Ca}(\mathrm{OH})_{2} / \mathrm{CaCl}_{2}\end{array}$} & Chloride \\
\hline $100 \mathrm{~g} \mathrm{~F} / \mathrm{Ash}$ & $\mathrm{N}$ & $W$ & $W$ & $\mathrm{~N}$ & $W$ & $M$ & \\
\hline $100 \mathrm{~g}$ DSG Sludge & $\mathrm{N}$ & $\mathrm{N}$ & $\mathrm{N}$ & $N$ & $N$ & $\mathrm{~N}$ & \\
\hline $100 \mathrm{~g}$ Bottom Ash & $\mathrm{N}$ & $\mathrm{M}$ & $\mathrm{W}$ & $\mathbb{N}$ & $W$ & M & \\
\hline $\begin{array}{l}50 \text { g Fly Ash + } \\
50 \text { g DSG Sludge }\end{array}$ & $\mathrm{N}$ & $N$ & $\mathrm{~N}$ & $\mathrm{~N}$ & $\mathrm{~N}$ & $\mathrm{~N}$ & \\
\hline $\begin{array}{lll}20 & \text { gly } & \text { Ash }+ \\
80 & \text { g } & \text { DSG Sludge }\end{array}$ & $\mathrm{N}$ & $\mathrm{N}$ & $N$ & $\mathrm{~N}$ & $\mathrm{~N}$ & $\mathrm{~N}$ & \\
\hline $\begin{array}{l}50 \mathrm{~g} \text { Fly Ash }+ \\
50 \mathrm{~g} \text { Bottom Ash }\end{array}$ & $\mathrm{N}$ & $N$ & $\mathrm{~N}$ & $\mathrm{~N}$ & $\mathrm{~N}$ & $\mathrm{~N}$ & \\
\hline $\begin{array}{l}50 \text { g Bottom Ash }+ \\
50 \text { g DSG Sludge }\end{array}$ & $\mathrm{W}$ & $\mathrm{N}$ & $\mathrm{N}$ & $\mathrm{N}$ & $\mathrm{N}$ & $\mathrm{N}$ & \\
\hline $\begin{array}{l}20 \mathrm{~g} \text { Bottom Ash }+ \\
80 \mathrm{~g} \text { DSG Sludge }\end{array}$ & $\mathrm{N}$ & $\mathrm{N}$ & $\mathrm{N}$ & $\mathrm{N}$ & $\mathrm{N}$ & $\mathrm{N}$ & \\
\hline $\begin{array}{l}33 \mathrm{~g} \mathrm{Fly} \mathrm{Ash}+33 \mathrm{~g} \\
\text { Bottom Ash }+34 \mathrm{~g} \text { DSG Sludge }\end{array}$ & $\mathrm{N}$ & $\mathrm{N}$ & $\mathrm{N}$ & $\mathrm{N}$ & $\mathrm{N}$ & $\mathrm{N}$ & \\
\hline $\begin{array}{l}14 \mathrm{~g} \text { Fly Ash }+14 \mathrm{~g} \\
\text { Bottom Ash }+72 \mathrm{~g} \text { DSG Sludge }\end{array}$ & $N$ & $\mathrm{~N}$ & $\mathrm{~N}$ & $\mathrm{~N}$ & $\mathrm{~N}$ & $\mathrm{~N}$ & \\
\hline
\end{tabular}


Power Plant

By-Product Tested

100 g Fly Ash

100 g DSG Sludge

$100 \mathrm{~g}$ Bottom Ash

50.g Fly Ash +

$50 \mathrm{~g}$ DSG Sludge

20 g Fly Ash +

$80 \mathrm{~g}$ DSG Sludge

50 g Fly Ash +

$50 \mathrm{~g}$ Bottom Ash

$50 \mathrm{~g}$ Bottom Ash +

$50 \mathrm{~g}$ DSG Sludge

$20 \mathrm{~g}$ Bottom Ash +

80 g DSG Sludge

$33 \mathrm{~g} \mathrm{Fly} \mathrm{Ash}+33 \mathrm{~g}$ Bottom Ash + 34 g DSG Sludge:

$14 \mathrm{~g} \mathrm{Fly} \mathrm{Ash} \mathrm{+} 14 \mathrm{~g}$ Bottorn N

Ash +72 g DSG Sludge
5 Parts Lime/1 Part Aluminum Sulfate $5 \mathrm{Ca}(\mathrm{OH})_{2} / \mathrm{AAl}_{2}\left(\mathrm{SO}_{4}\right)_{3}$

$1 \mathrm{~g} \quad 5 \mathrm{~g} \quad 10 \mathrm{~g}$

N N W

$\mathrm{N} \quad \mathrm{N} \quad \mathrm{N}$

N $\quad \mathrm{N} \quad \mathrm{W}$

N N N

$\mathrm{N} \quad \mathrm{N} \quad \mathrm{N}$

N W W

$\mathrm{N} \quad \mathrm{N} \quad \mathrm{N}$

$\begin{array}{lll}\mathrm{N} & \mathrm{N} & \mathrm{N}\end{array}$

$\mathrm{N} \quad \mathrm{N} \quad \mathrm{N}$

$\mathrm{N} \quad \mathrm{N}$

N
$\mathrm{N}$

$\mathrm{N}$

W

5 Parts Lime/1 Part Aluminum Sulfate $/ 2$ Parts Sodium Silicate $5 \mathrm{Ca}(\mathrm{OH})_{2} / 1 \mathrm{Al}_{2}\left(\mathrm{SO}_{4}\right)_{3} / 2 \mathrm{Na}_{2} \mathrm{SiO}_{3}$

$1 \mathrm{~g} \quad 5 \mathrm{~g} \quad 10 \mathrm{~g}$

$\begin{array}{lll}\text { N } & \text { H } & \text { H } \\ \text { N } & \text { N } & \text { N } \\ \text { W } & \text { M } & \text { H } \\ \text { N } & \text { N } & \text { N }\end{array}$

W $\quad$ M H

$\begin{array}{lll}\mathrm{N} & \mathrm{N} & \mathrm{N}\end{array}$

$\begin{array}{lll}\mathrm{N} & \mathrm{N} & \mathrm{N}\end{array}$

$\mathrm{N} \quad \mathrm{N} \quad \mathrm{N}$

$\mathrm{N} \quad \mathrm{N} \quad \mathrm{W}$

N $\quad \mathrm{N} \quad \mathrm{W}$


Proportions of Fly Ash, Bottom Ash, and Desulfurization

Gypsum (DSG) Sludge and Hardening Agents Used in

Test of Ohio Edison Waste Products. Hardening Results (after 60 days)

N - Nil (Plastic after 1 week), W - Weakly Hardened, M - Moderately

Hardened, H - Hardened (Resists Crushing), VH - very hard (resists

breaking and crushing under heavy pressure)

FA

$\mathrm{BA}$

DSG

$1: 1 \mathrm{FA} / \mathrm{DSG}$

$5: 1 \mathrm{FA} / \mathrm{DSG}$

$1: 1 \mathrm{FA} / \mathrm{BA}$

$1: 1 \mathrm{BA} / \mathrm{DSG}$

$5: 1 \mathrm{BA} / \mathrm{DSG}$

$1: 1: 1 \mathrm{FA} / \mathrm{BA} / \mathrm{DSG}$

$1: 1: 5 \mathrm{FA} / \mathrm{BA} / \mathrm{DSG}$

\section{Lime}

$1 \stackrel{\text { Lime }}{5} 10$

W W M

W $\mathrm{H} \quad \mathrm{VH}$

N W H

N W M

N M H

$\mathrm{N} N \mathrm{~N}$

N M H

N M H

$\mathrm{N} \quad \mathrm{N} \quad \mathrm{W}$

N W M
$\mathrm{CaCl}_{5}{ }_{10}$

N W H

$\begin{array}{lll}M & \mathrm{H} & \mathrm{VH}\end{array}$

N $\quad \mathrm{M} \quad \mathrm{H}$

$\mathrm{N}$ W $\mathrm{M}$

N W M

N W H

N W H

N W H

N W H

$\mathrm{N} W \mathrm{H}$

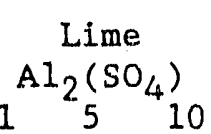

$\mathrm{N} \quad \mathrm{N} \quad \mathrm{H}$

N W W

$\mathrm{N}$ W $\mathrm{H}$

N W W

N W M

N N W

$\mathrm{N} N \mathrm{~W}$

N W M

N N N

N W H
Lime

$\mathrm{AlSO}_{4}$

Na Silicate

1510

W $\mathrm{H} \quad \mathrm{VH}$

W $\mathrm{H} \quad \mathrm{VH}$

W M M

N W H

$\begin{array}{lll}\mathrm{N} & \mathrm{H} & \mathrm{VH}\end{array}$

M H VH

W $M \quad V H$

N M VH

$\begin{array}{lll}\mathrm{N} & \mathrm{H} & \mathrm{VH}\end{array}$

N $\mathrm{H}_{\mathrm{VH}}$ 


\section{APPENDIX B}

\section{Flyash/Bottom Ash Mirtures for the Second}

Series of Hardening Tests

\section{OHIO COAL ASH}

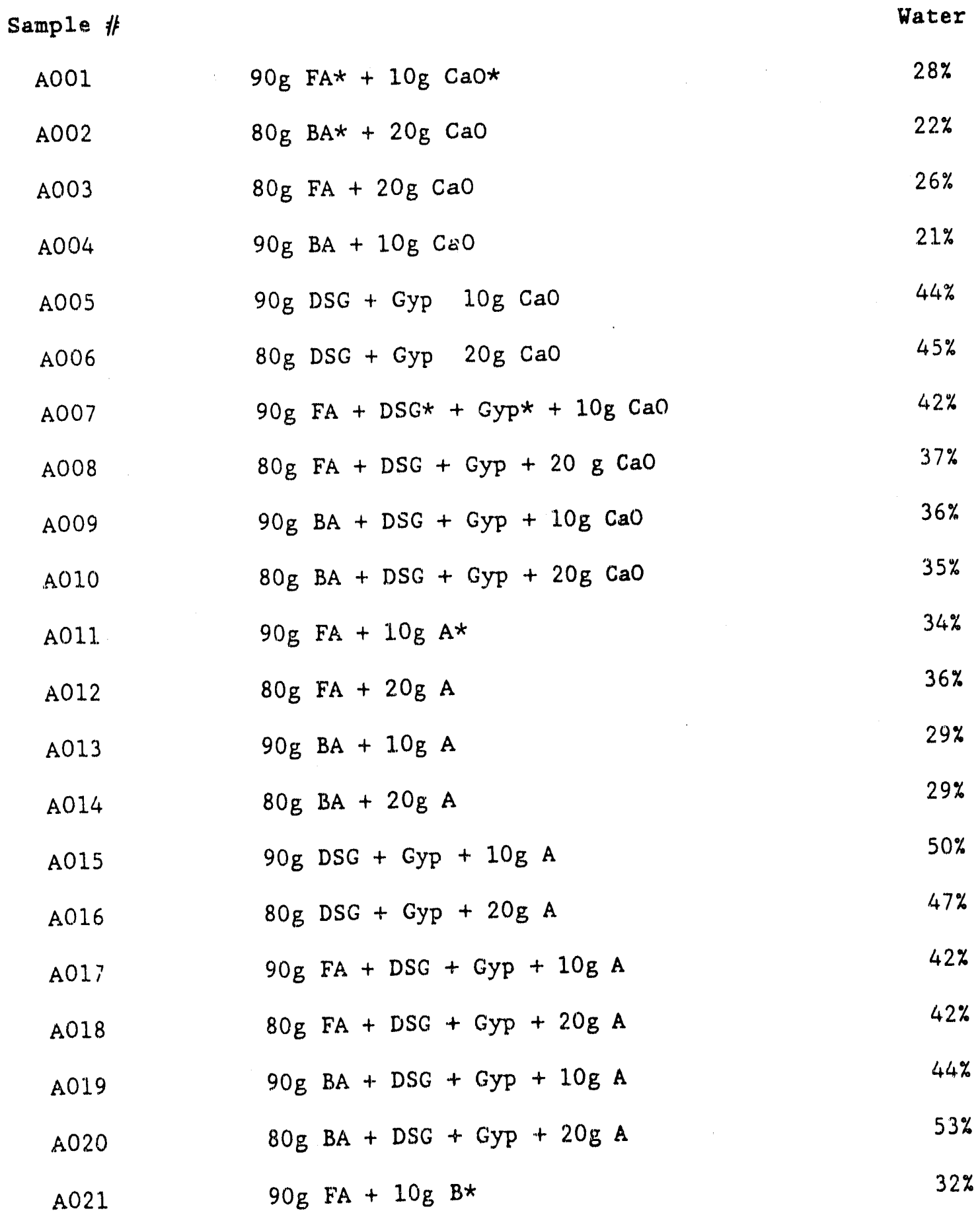




\begin{tabular}{|c|c|}
\hline $\mathrm{A} 022$ & $80 \mathrm{gFA}+20 \mathrm{gB}$ \\
\hline $\mathrm{A} 023$ & $90 \mathrm{~g} B A+10 \mathrm{~g} \mathrm{~B}$ \\
\hline A024 & $80 \mathrm{~g} B A+20 \mathrm{gB}$ \\
\hline A025 & $90 \mathrm{~g} D S G+G y p+10 g B$ \\
\hline $\mathrm{A} 026$ & $80 \mathrm{~g} D S G+6 y p+20 g B$ \\
\hline $\mathrm{A} 027$ & $90 \mathrm{~g} F A+D S G+$ Gyp $+10 g B$ \\
\hline A028 & $80 \mathrm{~g} F A+D S G+G y p+20 g B$ \\
\hline A029 & $90 \mathrm{~g} B A+D S G+G y p+10 g B$ \\
\hline $\mathrm{A} 030$ & $80 \mathrm{gBA}+\mathrm{DSG}+$ Gyp $+20 \mathrm{~g} B$ \\
\hline
\end{tabular}

TVA COAL ASH

Sample

Water

A031

$90 \mathrm{~g} \mathrm{FA}+10 \mathrm{~g} \mathrm{CaO}$

$39 \%$

$\mathrm{A} 032$

$80 \mathrm{~g} \mathrm{FA}+20 \mathrm{~g} \mathrm{CaO}$

$36 \%$

$\mathrm{A} 033$

$90 \mathrm{gFA}+\mathrm{DSG}+\mathrm{Gyp}+10 \mathrm{~g} \mathrm{CaO}$

$42 \%$

$\mathrm{A} 034$

$80 \mathrm{~g} \mathrm{FA}+\mathrm{DSG}+\mathrm{Gyp}+20 \mathrm{~g} \mathrm{CaO}$

$41 \%$

A035

$90 \mathrm{gFA}+\operatorname{log~A}$

$38 \%$

A036

$80 \mathrm{~g} \mathrm{FA}+20 \mathrm{~g} \mathrm{~A}$

$46 \%$

A037

$90 \mathrm{~g} F A+\mathrm{DSG}+\mathrm{Gyp}+10 \mathrm{gA}$

$45 \%$

A038

$90 \mathrm{~g} F A+10 \mathrm{gB}$

$40 \%$

A039

$80 \mathrm{gFA}+20 \mathrm{~g} \mathrm{~B}$

$39 \%$

A040

$80 \mathrm{gFA}+\mathrm{DSG}+\mathrm{Gyp}+20 \mathrm{gA}$

$41 \%$

A041

$90 \mathrm{gFA}+\mathrm{DSG}+\mathrm{Gyp}+10 \mathrm{gB}$

$45 \%$

A042

$80 \mathrm{gFA}+\mathrm{DSG}+\mathrm{Gyp}+20 \mathrm{gB}$

$41 \%$

A.043

$90 \mathrm{~g} \mathrm{FA} 2+10 \mathrm{~g} \mathrm{CaO}$

$42 \%$

$\mathrm{A} 044$

$80 \mathrm{~g} \mathrm{FA} 2+20 \mathrm{~g} \mathrm{CaO}$

$40 \%$

A045

$90 \mathrm{~g} \mathrm{FA} 2+\mathrm{DSG}+\mathrm{Gyp}+10 \mathrm{~g} \mathrm{CaO}$

$44 \%$

A046

$80 \mathrm{gFA} 2+\mathrm{DSG}+\mathrm{Gyp}+20 \mathrm{~g} \mathrm{CaO}$

$41 \%$ 


\begin{tabular}{|c|c|c|}
\hline A047 & $90 \mathrm{gFA} 2+10 \mathrm{~g} \mathrm{~A}$ & $42 \%$ \\
\hline $\mathrm{A} 048$ & $80 \mathrm{gFA} 2+20 \mathrm{~g} \mathrm{~A}$ & $45 \%$ \\
\hline A.049 & $90 \mathrm{gFA} 2+\mathrm{DSG}+\mathrm{Gyp}+10 \mathrm{gA}$ & $44 \%$ \\
\hline A050 & $80 \mathrm{gFA} 2+\mathrm{DSG}+\mathrm{Gyp}+20 \mathrm{gA}$ & $41 \%$ \\
\hline A051 & $90 \mathrm{gFA} 2+10 \mathrm{~g} \mathrm{~B}$ & $42 \%$ \\
\hline A052 & $80 \mathrm{gFA} 2+20 \mathrm{gB}$ & $37 \%$ \\
\hline $\mathrm{A} 053$ & $90 \mathrm{~g} F A 2+D S G+$ Gyp $+10 \mathrm{~g} \mathrm{~B}$ & $\cdots$ \\
\hline A078 & $80 \mathrm{~g} F A 2+\mathrm{DSG}+$ Gyp $+20 \mathrm{~g} B$ & $\cdots$ \\
\hline & WHITE BLUFF COAL ASH & \\
\hline A.054 & $90 \mathrm{~g} \mathrm{BA}+10 \mathrm{~g} \mathrm{CaO}$ & $21 \%$ \\
\hline A055 & $80 \mathrm{~g} \mathrm{BA}+20 \mathrm{~g} \mathrm{CaO}$ & $22 \%$ \\
\hline A056-A & $90 \mathrm{gBA}+\log A$ & $29 \%$ \\
\hline A056-B & $90 \mathrm{gBA}+10 \mathrm{gA}$ & $26 \%$ \\
\hline A057 & $80 \mathrm{~g} \mathrm{BA}+20 \mathrm{~g} \mathrm{~A}$ & $27 \%$ \\
\hline A058 & $90 \mathrm{gBA}+10 \mathrm{~g} \mathrm{~B}$ & $25 \%$ \\
\hline A059 & $80 \mathrm{gBa}+20 \mathrm{~g} \mathrm{~B}$ & $26 \%$ \\
\hline A060 & $90 \mathrm{~g}[\mathrm{BA}+\mathrm{DSG}+\mathrm{Gyp}]+10 \mathrm{~g} \mathrm{CaO}$ & $34 \%$ \\
\hline A061 & $80 \mathrm{~g}[\mathrm{BA}+\mathrm{DSG}+\mathrm{Gyp}]+20 \mathrm{~g} \mathrm{CaO}$ & $35 \%$ \\
\hline A062 & $90 \mathrm{~g}[\mathrm{BA}+\mathrm{DSG}+$ Gyp $]+10 \mathrm{~g} A$ & $37 \%$ \\
\hline A063 & $80 \mathrm{~g}[\mathrm{BA}+\mathrm{DSG}+$ Gyp $]+20 \mathrm{~g} A$ & $39 \%$ \\
\hline A064 & $90 \mathrm{gBa}+\mathrm{DSG}+$ Gyp $+10 \mathrm{gB}$ & $36 \%$ \\
\hline A065 & $80 g^{\prime}[B A+D S G+G y p]+20 g B$ & $38 \%$ \\
\hline A066 & $90 \mathrm{~g} \mathrm{FA}+10 \mathrm{~g} \mathrm{CaO}$ & $22 \%$ \\
\hline A.067 & $80 \mathrm{~g} \mathrm{FA}+20 \mathrm{~g} \mathrm{CaO}$ & $28 \%$ \\
\hline A068 & $90 \mathrm{gFA}+\mathrm{DSG}+10 \mathrm{~g} \mathrm{CaO}$ & $37 \%$ \\
\hline A069 & $80 \mathrm{gFA}+\mathrm{DSG}+20 \mathrm{~g} \mathrm{CaO}$ & $35 \%$ \\
\hline
\end{tabular}




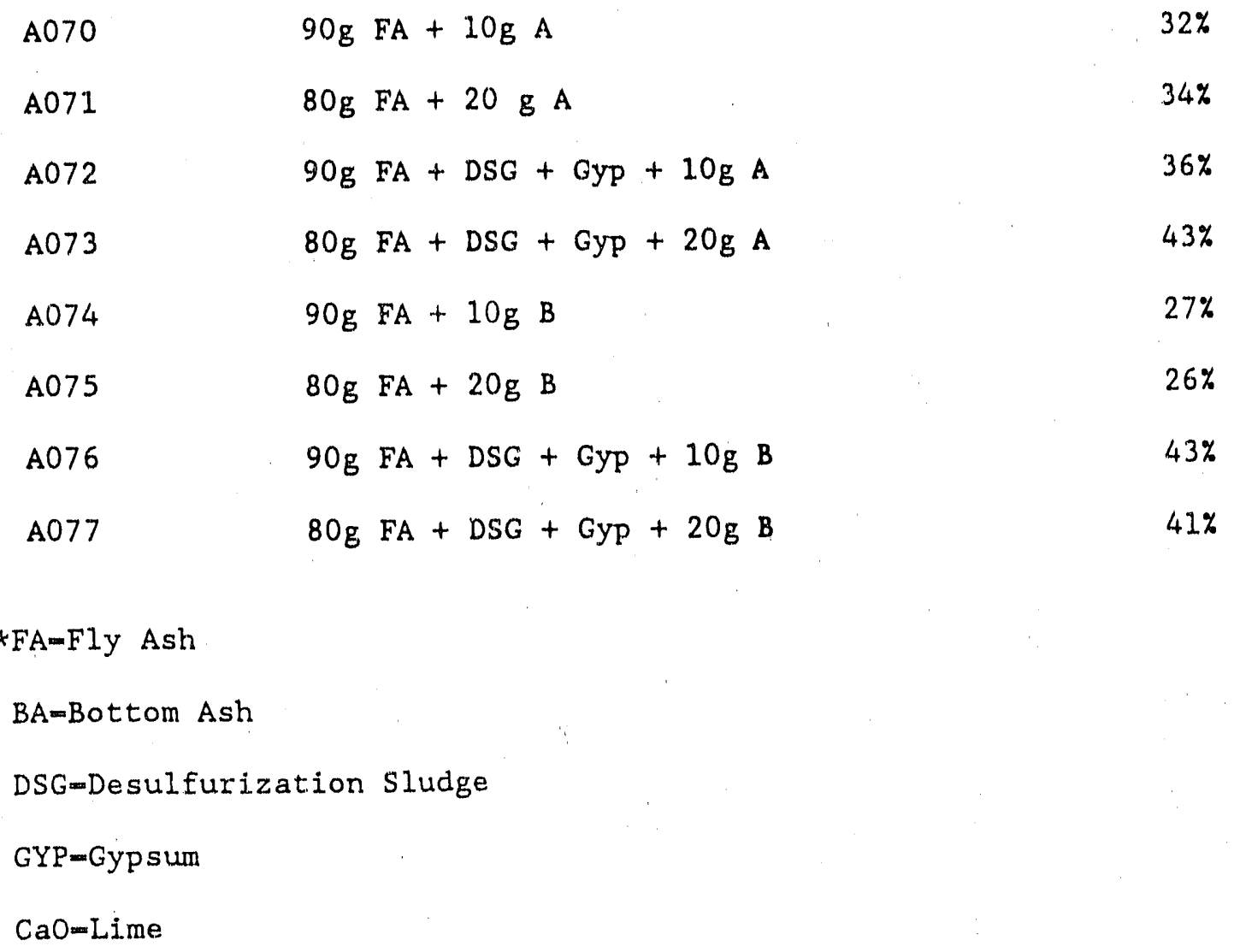




\section{APPENDIX C}

\section{Test Sample Characteristics from the Second Series of Hardening Tests}

Sample:

A001 - Sample is hard. Does not demonstrate shrinkage or expansion cracks.

A002 - Hard. Cup is bulged from approximately $10 \%$ expansion.

A003 - Cup is split from approximately 20\% expansion. Sample is hard and demonstrates very minor surface cracking.

A004 - Exhibits minor shrinkage (after an apparent expansion because the cup is slightly bulged).

A005 - Hard. Demonstrates minor surface cracking and spalling but no apparent shrinkage or expansion.

A006 - Demonstrates some surface expansion and spalling of the surface. There is a ring around the surface of the cup where it expanded more than the body of the mix.

A007 - Demonstrates considerable surface cracking and spalling and expansion of the surface layer.

A008 - Demonstrates minor expansion. There is some cracking evident. No surface spalling.

A009 - Demonstrates considerable cracking. Some minor surface spalling, minor expansion.

A010 - Hardened. Does not demonstrate appreciable surface cracking or expansion. No apparent shrinkage.

A011 - Demonstrates minor shrinkage after apparent expansion. No surface cracking, no spalling.

A012 - Demonstrates minor, probably less than $5 \%$, expansion followed by some shrinkage. No surface spaliing al though the surface is somewhat soft.

A013 - Demonstrates considerable shrinkage. No surface cracking.

A014 - Demonstrates minor expansion and cracks. Surface is irregular, somewhat soft.

A015 - Demonstrates considerable expansion, surface spalling, and very deep cracks.

A016 - Demonstrates no appreciable expansion; however, the surface has spalled and there are a considerable number of fine cracks throughout the body of the material. 
A017 - Demonstrates severe surface spalling and severe cracking, although expansion appears to be only about $5 \%$.

A018 - Demonstrates minor surface spalling, considerable cracking, no apparent expansion or shrinking.

A019 - Demonstrates severe surface spalling, severe surface cracking and cracking through the body of the material. Extreme expansion or contraction not evident in the cup.

A020 - Demonstrates some shrinkage, minor surface spalling, minor cracking.

A021 - Sample is crumbly, soft, surface is spalled, probably cracked, although it is difficult to tell. No expansion or shrinkage is evident.

A022 - Sample appears to have expanded approximately $10 \%$. Minor surface spalling, mostly in the center of the sample and some cracking is evident.

A023 - Specimen has severe surface cracking and spalling. Sample appears to have undergone minor expansion.

A024 - Specimen is fairly hard. Minor surface spalling and some cracking is evident.

A025 - Specimen is hard. Appears to have been some expansion followed by shrinkage. Minor surface spalling, minor cracking apparent.

A026 - Considerable surface spalling. No expansion or shrinkage apparent. Considerable cracking of the sample.

A027 - Hard. There is minor surface spalling, no cracking is evident. Sample appears to have minor shrinkage.

A028 - Appears to have expanded approximately 10\%. There is considerable minor surface spalling. Underneath the surface layer are fairly large cracks.

A029 - Appears to have expanded and then shrunk. There is only minor surface spalling but considerable cracking of the sample.

A030 - Has surface spalling. Does not appear to have expanded. There is apparently some shrinkage on drying. Minor cracking.

A031 - Has shrunk considerably. There is no evidence of cracking, there is some minor surface spalling.

A032 - Has very minor surface spalling. Sample is hard, does not appear to have been either shrinkage or expansion.

A033 - Hard. Does not appear to have either expanded or shrunk. Minor surface spalling, minor cracking.

A034 - Hard. There is very minor cracking, no evident surface spalling. 
A035 - Has very minor surface spalling, appears to have minor shrinkage and very minute cracking.

A036 - Minor surface spalling. Sample is hard, does not appear to be cracked. A037 - Considerable surface spalling. Formation of crystalline crust and cracks throughout.

A038 - Has crumbled into small fragrments. Appears to be cracked throughout. Does not appear to have either expanded or contracted; however, it is falling apart.

A039 - Hard. Exhibits very minor surfac spalling. No evident cracking. Does not appear to have shrunk or expandec

A040 - Appears to have shrunk. Sample is reasonably hard. Does not show surface cracking or spalling.

A041 - Shows cunsiderable surface spalling. Minor cracking, although it is hard to determine with all of the spalling. Does not appear to have shrunk or. expanded.

A042 - Appears to have expanded approximately $10 \%$ with most of the expansion concentrated to the surface of the sample. Sample has minor surface spalling and extensive deep cracking.

A043 - Does not show surface spalling or cracking. Does not appear to have expanded or contracted.

A044 - Shows very minor surface spalling. No cracking is evident. Sample does not appear to have shrunk or expanded.

A045 - Does not show expansion or contraction. Very minor cracking and no surface spalling evident.

A046 - Shows considerable shrinkage with one large crack extending completely across the specimen. Sample is very soft.

A047 - Shows minor surface spalling, no cracking. Does appear to be some minor shrinkage. Sample is reasonably hard.

A048 . Hard. Shows very minor surface spalling, no cracking. No evidence of expansion or shrinkage.

A049 - Appears to have expanded slightly with most of the expansion at the top of the sample. Surface has minor spalling but very extensive deep cracking.

A050 - Shows minor expansion of the surface. There is minor spalling and considerable number of surface cracks.

A051 - Soft. Shows no evidence of shrink or swell. Surface is spalling. There is minor cracking.

A052 - Shcws no evidence of surface spalling or cracking; however, it is very 
soft.

A054 - Hard. Does not appear to havr expanded or contracted. Does not show surface spalling or cracking.

A055 - Shows extreme expansion, probably $20 x$ because : he sample burst the cup, does not show surface spalling, does not show surface cracking.

A056A - Does not show expansion or contraction. Very minor surface spalling and one crack.

A053 - Shows considerable surface spalling but no cracking is in evidence. Does not appear to have expanded or contracted.

A077 - Shows minor surface spalling, considerable cracking. Sample appears to have expanded $10 \%$.

A078 - Shows a loose powdery surface, considerable spalling, no cracking is evident. No expansion or contraction is evidnnt, sample is fairly hard.

A058 - Shows minor expansion of the surface. The surface is fairly loose. There is ainor spalling. Sample is soft.

A057 - Shows considerable expansion, approximately $10 \%$, perhaps a little more. Does not show surface spalling; however, there are several large deep cracks in the sample.

A056B - Shows approxima:ely $5 \%$ expansion. Sample has no surface spalling evident; however, it has a considerable network of fine cracks throughout it.

A059 - Shows approximately $5 \%$ expansion with the bottom layer having expanded 10\%. Sample shows winor surface spalling, considerable fine crack network throughout.

A060 - Shows approximately $5 \%$ expansion. Sample has some surface spalling and very minor fine cracking.

A061 - Shows no evidence of expansion or contraction. Minor surface spalling and no cracking is evident.

A064 - Shows minor expansion followed by contraction. Sample is extensively spalled on the surface. Has considerable deep cracks.

A063 - Shows approximately $5 \%$ expansion with most of it concentrated near the surface of the sample. Surface has very minor spalling and considerable fine cracks.

A062 - Shows minor expansion, probably less than $5 \%$. Sample has minor surface spalling and considerable fine surface cracks.

A065 - The surface is completely covered by a fibrous mineral so it is impossible to determine whether there is any cracking or not. Sample does not appear to have expanded and is hard. 
A066 - Sample appears to have expanded approximately 5\%. Surface has very minor spalling, considerable fine cracking with a few cracks that are deep.

A067 - Has expanded approximately 20\%. Surface has minor spalling and considerable fine cracks.

A070 - Shows no surface spalling, no surface cracks, does not appear to have expanded or contracted.

A069 - Shows approximately 20 expansion, minor surface spalling, very minor fine cracking.

A068 - Has very minor expansion, probahly 1-2\% mostly at the surface, shows very minor surface spalling and very fine minor cracks.

A071 - Has approximately 2-3\% expansion mostly concentrated near the surface of the sample, does not show spalling, and has very, very minor fine cracking across the surface.

A072 - Does not appear to have expanded. Sample has minor surface spalling, considerable fine cracking.

A073 - Appears to have expanded 1-2\% as minor surface spalling, considerable cracking arranged in a radial pattern.

A074 - Appears to have expanded 1-2\%. Surface has very minor spalling and minor fine cracking.

A075 - Appears to have expanded approximately 5\%. Sample has not spalled, surface has extremely minor fine cracking.

A076 - Appears to have expanded approximately 5\%, most concintrated near the top of the sample. Sample has minor surface spalling and considerable cracking rat-acing from the center of the sample. 


\section{APPENDIX D}

\section{Cation Exchange Capacities for}

Various Hardening Mixtures

\begin{tabular}{|c|c|c|c|}
\hline Sample \# & Mixture & $\mathrm{H}_{2} \mathrm{O}$ & $\mathrm{meq} / 100_{\mathrm{g}}$ \\
\hline $\mathrm{A} 002$ & $80 \mathrm{~g} \mathrm{BA} *+20 \mathrm{~g} \mathrm{CaO} *$ & $22 \%$ & 8.3 \\
\hline A003 & $80 \mathrm{~g} \mathrm{FA}+20 \mathrm{~g} \mathrm{CaO}$ & $26 \%$ & 16.6 \\
\hline A006 & $80 \mathrm{~g} \mathrm{DSG} *+$ Gyp* $20 \mathrm{~g} \mathrm{CaO}$ & $45 \%$ & 5.5 \\
\hline A008 & $80 \mathrm{gFA}+\mathrm{DSG}+\mathrm{Gyp}+20 \mathrm{~g} \mathrm{CaO}$ & $37 \%$ & 11.1 \\
\hline A010 & $80 \mathrm{gBA}+\mathrm{DSG}+\mathrm{Gyp}+20 \mathrm{~g} \mathrm{CaO}$ & $35 \%$ & 2.8 \\
\hline A012 & $80 \mathrm{gFA}+20 \mathrm{~g} A *$ & $36 \%$ & 2.8 \\
\hline A014 & $80 \mathrm{gBA}+20 \mathrm{~g} \mathrm{~A}$ & $29 \%$ & 2.8 \\
\hline A016 & $80 \mathrm{~g} \mathrm{DSG}+$ Gyp $+20 \mathrm{~g} \mathrm{~A}$ & $47 \%$ & 3.9 \\
\hline $\mathrm{A} 018$ & $80 \mathrm{gFA}+\mathrm{DSG}+\mathrm{Gyp}+20 \mathrm{gA}$ & $42 \%$ & 3.9 \\
\hline $\mathrm{A} 020$ & $80 g B A+D S G+G y p+20 g A$ & $53 \%$ & 2.8 \\
\hline A022 & $80 \mathrm{gFA}+20 \mathrm{gB} \mathrm{B}^{*}$ & $32 \%$ & 5.5 \\
\hline $\mathrm{A024}$ & $80 \mathrm{gBA}+20 \mathrm{gB}$ & $28 \%$ & 3.9 \\
\hline A026 & $80 \mathrm{~g} D S G+$ Gyp $+20 \mathrm{gB}$ & $48 \%$ & 2.8 \\
\hline $\mathrm{A} 028$ & $80 \mathrm{gFA}+\mathrm{DSG}+\mathrm{Gyp}+20 \mathrm{gB}$ & $41 \%$ & 0.5 \\
\hline $\mathrm{A} 030$ & $80 g B A+D S G+G y p+20 g B$ & - & 0.5 \\
\hline A.032 & $80 \mathrm{~g} \mathrm{FAI}+20 \mathrm{~g} \mathrm{CaO}$ & $36 \%$ & 3.9 \\
\hline A034 & $80 \mathrm{gFAl}+\mathrm{DSG}+\mathrm{Gyp}+20 \mathrm{~g} \mathrm{CaO}$ & $41 \%$ & 5.5 \\
\hline A036 & $80 \mathrm{~g} F A 1+20 \mathrm{gA}$ & $46 \%$ & 2.8 \\
\hline A.039 & $80 \mathrm{gFAl}+20 \mathrm{gB}$ & $39 z$ & 12.8 \\
\hline $\mathrm{A} 040$ & $80 \mathrm{gFAI}+\mathrm{DSG}+\mathrm{Gyp}+20 \mathrm{gA}$ & $41 \%$ & 6.1 \\
\hline $\mathrm{A} 042$ & $80 \mathrm{gFAI}+\mathrm{DSG}+\mathrm{Gyp}+20 \mathrm{gB}$ & $4 I \%$ & 5.5 \\
\hline $\mathrm{A} 044$ & $80 \mathrm{gFA} 2+20 \mathrm{~g} \mathrm{CaO}$ & $40 \%$ & 5.5 \\
\hline AC46 & $80 \mathrm{~g} F A 2+D S G+G y p+20 \mathrm{~g} \mathrm{CaO}$ & $41 \%$ & 5.5 \\
\hline & $D-1$ & & \\
\hline
\end{tabular}




\begin{tabular}{|c|c|c|c|}
\hline A048 & $80 \mathrm{gFA2}+20 \mathrm{~g} \mathrm{~A}$ & $45 \%$ & 5.5 \\
\hline A050 & $80 \mathrm{gFA2}+\mathrm{DSG}+\mathrm{Gyp}+20 \mathrm{gA}$ & $41 \%$ & 2.8 \\
\hline A052 & $80 \mathrm{~g} F A 2+20 \mathrm{gB}$ & $37 \%$ & 2.8 \\
\hline A078 & $80 \mathrm{gFA} 2+\mathrm{DSG}+\mathrm{Gyp}+20 \mathrm{gB}$ & $\cdots$ & 2.8 \\
\hline A055 & $80 \mathrm{~g} \mathrm{BA}+20 \mathrm{~g} \mathrm{CaO}$ & $22 \%$ & 5.5 \\
\hline A057 & $80 \mathrm{gBA}+20 \mathrm{~g} \mathrm{~A}$ & $27 \%$ & 2.8 \\
\hline A059 & $80 \mathrm{~g} \mathrm{Ba}+20 \mathrm{~g} \mathrm{~B}$ & $26 \%$ & 2.8 \\
\hline A061 & $80 \mathrm{~g}[\mathrm{BA}+\mathrm{DSG}+\mathrm{Gyp}]+20 \mathrm{~g} \mathrm{CaO}$ & $35 \%$ & 2.8 \\
\hline $\mathrm{A} 063$ & $80 \mathrm{~g}[\mathrm{BA}+\mathrm{DSG}+\mathrm{Gyp}]+20 \mathrm{~g} A$ & $39 \%$ & 2.8 \\
\hline A065 & $80 \mathrm{~g}[\mathrm{BA}+\mathrm{DSG}+\mathrm{Gyp}]+20 \mathrm{~g} B$ & $38 \%$ & 9.4 \\
\hline A067 & $80 \mathrm{gFA}+20 \mathrm{~g} \mathrm{CaO}$ & $28 \%$ & 2.8 \\
\hline A069 & $80 \mathrm{gFA}+\mathrm{DSG}+20 \mathrm{~g} \mathrm{CaO}$ & $35 \%$ & 1.7 \\
\hline $\mathrm{A} 071$ & $80 \mathrm{~g} F A+A$ & $34 \%$ & 1.7 \\
\hline A073 & $80 \mathrm{~g} F A+D S G+G y p+20 g A$ & $43 \%$ & 1.7 \\
\hline $\mathrm{A} 075$ & $80 \mathrm{gFA}+20 \mathrm{~g} \mathrm{~B}$ & $26 \%$ & $\cdots$ \\
\hline A077 & $80 \mathrm{gFA}+\mathrm{DSG}+\mathrm{Gyp}+20 \mathrm{~g} B$ & $41 \%$ & 0.5 \\
\hline
\end{tabular}

BAmbottom Ash

CaOmime

FAm-Fly Ash

DSG=Desulfurization Sludge

Gyp-Gypsum

$\mathrm{A}-3$ parts $\mathrm{CaO}+1$ part $\mathrm{Al}_{2}\left(\mathrm{SO}_{4}\right)_{3}$

$\mathrm{B}=3$ parts $\mathrm{CaO}+1$ part $\mathrm{Al}_{2}\left(\mathrm{SO}_{4}\right)_{3}+1$ part $\mathrm{Na}_{2} \mathrm{SiO}_{3}$ 


\section{APPENDIX E}

Adsorption of Heavy Metals by Hardened Product

\begin{tabular}{ccrrrrrrr}
$\begin{array}{c}\text { Sample } \\
\text { No. }\end{array}$ & $\begin{array}{c}\text { PPM } \\
\text { Added }\end{array}$ & As & Co & PPM Adsorbed & Cu & Se & Zn & Hg \\
\hline A003 & 10 & 10 & 10 & 10 & 10 & 10 & 10 & 10 \\
A008 & 10 & 5 & 10 & 10 & 10 & 10 & 10 & 10 \\
A028 & 10 & 10 & 10 & 10 & 10 & 10 & 10 & 10 \\
A030 & 10 & 10 & 10 & 10 & 10 & 5 & 8 & 10 \\
A055 & 10 & 9 & 10 & 10 & 10 & 10 & 10 & 10 \\
A059 & 10 & 5 & 10 & 10 & 10 & 7 & 10 & 10 \\
A065 & 10 & 9 & 10 & 10 & 10 & 10 & 8 & 10 \\
A067 & 10 & 10 & 10 & 10 & 10 & 10 & 10 & 10 \\
A075 & 10 & 7 & 10 & 10 & 10 & 8 & 8 & 10 \\
A003 & 50 & 10 & 50 & 50 & 50 & 14 & 21 & 40 \\
A008 & 50 & 15 & 50 & 50 & 50 & 15 & 25 & 50 \\
A028 & 50 & 11 & 50 & 50 & 50 & 28 & 20 & 50 \\
A030 & 50 & 0 & 50 & 45 & 50 & 3 & 31 & 50 \\
A055 & 50 & 38 & 50 & 43 & 50 & 15 & 20 & 42 \\
A059 & 50 & 0 & 50 & 40 & 50 & 13 & 20 & 50 \\
A065 & 50 & 10 & 50 & 45 & 50 & 2 & 26 & 50 \\
A067 & 50 & 40 & 50 & 50 & 50 & 17 & 22 & 46 \\
A075 & 50 & 8 & 50 & 42 & 50 & 14 & 25 & 45 \\
A003 & 100 & 11 & 100 & 100 & 100 & 12 & 33 & 71 \\
A008 & 100 & 6 & 100 & 100 & 97 & 22 & 45 & 100 \\
A028 & 100 & 10 & 100 & 100 & 100 & 21 & 22 & 100 \\
A030 & 100 & 8 & 100 & 76 & 100 & 21 & 53 & 100 \\
A055 & 100 & 35 & 100 & 76 & 100 & 40 & 27 & 0 \\
A059 & 100 & 3 & 100 & 40 & 100 & 13 & 19 & 100 \\
A065 & 100 & 3 & 100 & 100 & 100 & 9 & 34 & 100 \\
A067 & 100 & 17 & 100 & 70 & 100 & 43 & 7 & 62 \\
A075 & 100 & 19 & 100 & 33 & 100 & 42 & 14 & 89 \\
& & & & & & & &
\end{tabular}



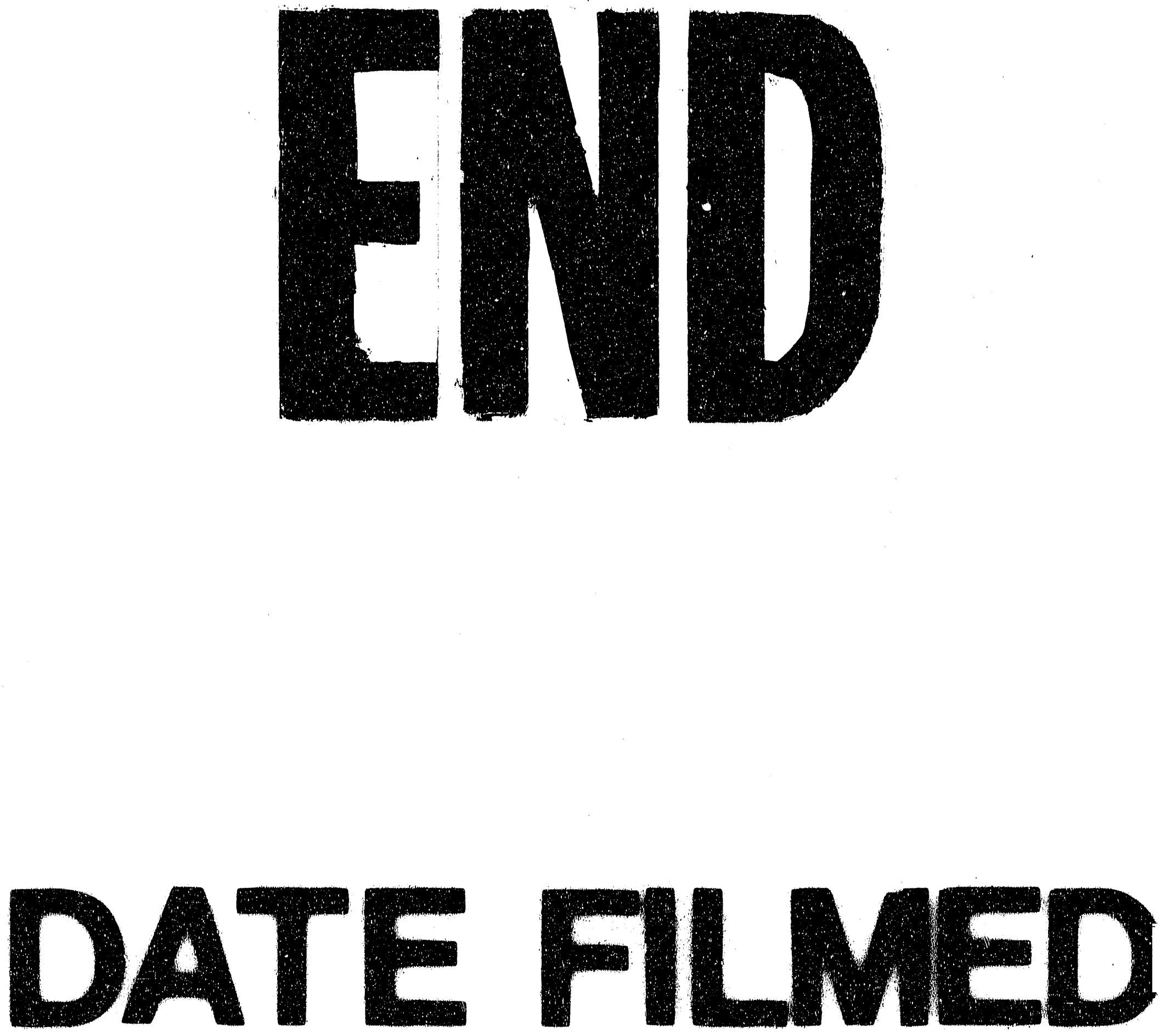

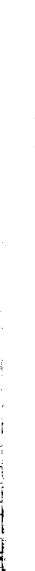
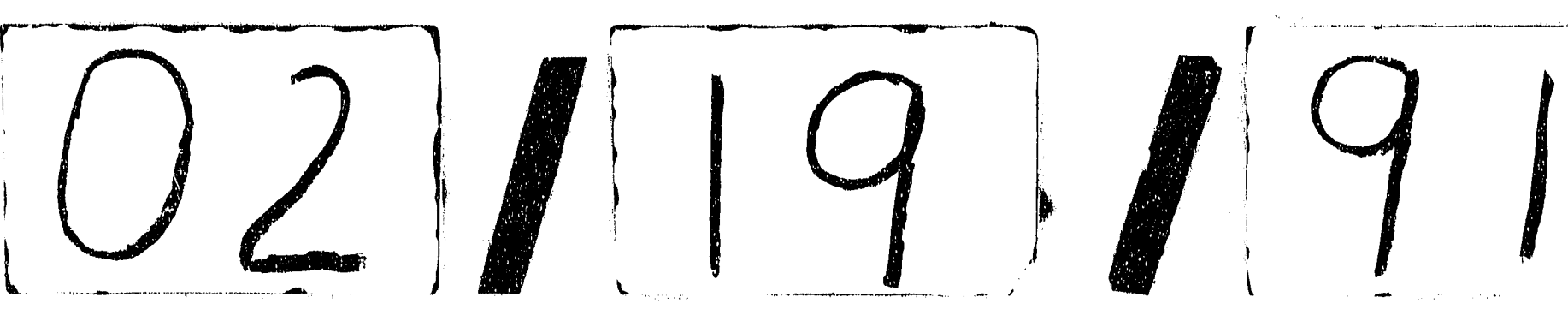
